\title{
TOLERANCE VALUES AND EFFECTS OF SELECTED ENVIRONMENTAL DETERMINANTS ON DIATOM DISTRIBUTION IN NORTHWEST AND NORTH CENTRAL WASHINGTON, USA
}

\author{
Dean W. Blinn ${ }^{1}$
}

\begin{abstract}
Diatoms were collected at 165 stream, river, wall seep, and pond/lake sites in 9 counties in northwest and north central Washington, including the Olympic Pennsisula, over a 5-year period. Four hundred and fifteen species in 77 genera were identified. Species assemblages were compared to altitude, physicochemical factors, aquatic habitats, and land use on west and east sides of the North Cascade Range. Species richness averaged 30.5 per site on the west side and 43 on the east side. Diatom species richness showed significant positive correlations to total nitrogen, total phosphorus, $\mathrm{pH}$, specific conductance, channel embeddedness, and water temperature, and a significant negative correlation to percent canopy cover. A multilevel hierarchical clustering model separated streams, rivers, wall seeps, and ponds/lakes into geographic and land-use regions based on diatom assemblages. A multimetric index (diatom tolerance index [DTI]) was developed to determine environmental tolerance levels for diatom species over a large number and variety of sites. The index performed well in distinguishing between the role of embeddedness, total nitrogen, total phosphorus, and specific conductance on the distribution of diatom species and showed close agreement between land use and diatom distribution. These DTI values provide baseline information for monitoring changes in ecosystem health in drainages throughout Washington landscapes. Didymosphenia geminata occurred in $46 \%$ of the streams and rivers sampled and ranged from $<1 \%$ to $27 \%$ in relative abundance, but it was not collected in ponds/lakes or wall seeps. Didymosphenia geminata density showed a significant positive correlation to suspended sediment and significant negative correlations to altitude and total nitrogen. This invasive alga attained a higher average relative abundance in rivers compared to streams and occurred in $28 \%$ of the sites examined west of the Cascade Range compared to $63 \%$ of the sites east of the Cascades.
\end{abstract}

Resumen.-Se colectaron diatomeas en 165 arroyos, ríos, paredes filtradas y estanques/lagos de 9 condados del noroeste y centro-norte de Washington, incluyendo la Península Olímpica, durante un período de 5 años. Se identificaron cuatrocientas quince especies de 77 géneros. Se compararon los grupos de especies con respecto a la altitud, los factores fisicoquímicos, los hábitats acuáticos y el uso de suelo en los el este y oeste de la Cordillera de las Cascadas del Norte (North Cascade Range). La riqueza de especies tuvo un promedio de 30.5 en cada ubicación de la zona oeste y 43 en el lado este. Se obtuvieron correlaciones positivas significativas entre la riqueza de especies y el nitrógeno total, fósforo total, el $\mathrm{pH}$, la conductividad específica, la incrustación en la acequia y la temperatura del agua, y una correlación negativa significativa con el \% de cobertura vegetal. Un modelo de agrupación jerárquica multinivel separó los arroyos, los ríos, las paredes filtradas y los estanque/lagos en regiones geográficas y el uso de suelo, basándose en las asociaciones de diatomeas. Se desarrolló un índice multimétrico [Tolerancia Diatomea Index (DTI, por sus siglas en inglés)] para determinar los niveles de tolerancia ambiental en especies de diatomeas a lo largo de un gran número y variedad de ubicaciones. El índice funcionó bien a la hora de distinguir entre el papel jugado por la incrustación, el nitrógeno total, el fósforo total y la conducción específica sobre la distribución de especies de diatomeas, y mostró una estrecha concordancia entre el uso de suelo. Estos valores DTI proporcionan información de referencia para el seguimiento de los cambios en la salud de los ecosistemas en pozos a lo largo de Washington. Se encontró Didymosphenia geminata en el $46 \%$ de los arroyos y ríos medidos, la abundancia relativa osciló entre $<1 \%$ al $27 \%$, pero no se colectó en estanques/lagos o paredes filtradas. Se encontró una correlación positiva significativa entre la densidad de D. geminata con los sedimentos en suspensión y con la altitud y el nitrógeno total se encontraron correlaciones negativas significativas. Esta alga invasora alcanza una mayor abundancia relativa promedio en ríos en comparación con arroyos, y se encontró en el $28 \%$ de las zonas inspeccionadas al oeste de la Cordillera de las Cascadas, en comparación con el 63\% de las zonas al este de las Cascadas.

Few studies have been published on the distribution and ecology of diatoms in the state of Washington, even though the state contains habitats ranging from low agricultural lands to shrubsteppe ecosystems, rainforests on the Olympic Pennisula, and true alpine habitats. The high diversity of ecoregions in Washington should yield equally high diversity in diatom assemblages.

One of the earliest publications on diatoms in the state was by Sovereign (1963) who described 27 species of diatoms from springs

${ }^{1}$ Department of Biological Sciences, Northern Arizona University, Flagstaff, AZ 86011. E-mail: deandiacad@gmail.com 
and lakes throughout the state. Blinn (1993) described the role of salinity on diatom communities in 3 salt lakes in the interior of Washington. Also, Bahls (2004-2006) provided a photographic catalogue with optima physicochemical values, as well as a checklist from northwestern USA (Bahls 2009) of 118 genera and 380 diatom species for the state of Washington.

Other Washington-based research has examined diatoms in sediment cores to depict environmental and climatic changes over time (Bennett 1962, Stockner and Benson 1967, Tynni 1986, Wallace et al. 2006). Also, Hollingshead (2012) examined climate and hydrologic changes in Castor Lake, and Enache et al. (2013) reported 3 new Psammothidium species in sediment cores from oligotrophic lakes in Washington Cascade Mountain Lakes. Recently, Sheibley et al. (2014) noted an increase in Asterionella formosa and Fragilaria tenera in sediment cores from Hoh Lake in Olympic National Park beginning in 19691975 which suggested nitrogen enrichment during this period.

Hawkins and Norris (2000) suggested that indices based on the most robust and finest taxonomic resolution are preferable over family or generic resolution for the bioassessment of habitats and landscapes. In addition, Barbour et al. (1995) recommended a multimetric approach for measuring biological conditions. Stevenson et al. (2008) hypothesized that indicators based on species traits determined in streams with similar natural landscape features would be most effective in developing tolerance indices. More recently, Stevenson (2014) further suggested that future research on the regional-scale resilience of algal assemblages will improve water quality management. Kociolek (2006) discussed the limited checklists of diatom taxa for various regions in the USA and the need to develop species lists for various regions, especially regions such as the state of Washington with a wide variety of geomorphic conditions, land use, and aquatic habitats.

The distribution and ecology of diatoms were examined in the state of Washington, with tolerance values for common diatom species based on channel embeddedness, nutrients (total nitrogen [TN], total phosphorus $[\mathrm{TP}])$, and specific conductance. These tolerance values provide a functional baseline for monitoring changes in ecosystem health for aquatic ecosystems in the varied landscapes of the state (Blinn and Ruiter 2013).

Northwestern Washington is experiencing a rapid expansion in agricultural activities and urban centers (Washington State Agriculture: 2025; www.agr.wa.gov). This study provides physicochemical and biotic baselines to monitor future changes in aquatic ecosystems in northwestern Washington. The following objectives were addressed in this paper: (1) determine the diatom flora in the northwest and central portions of the state of Washington, including the Olympic Pennisula; (2) determine the role land use plays in determining the diatom flora on the west and east sides of the Cascade Range; (3) develop a multimetric index to determine environmental tolerance levels to embeddedness, TN, TP, and specific conductance for dominant diatom species in the region; (4) determine the distribution and relative abundance of the invasive Didymosphenia geminata on the west and east sides of the Cascade Range.

\section{Study AREA}

The study area encompasses about 50,000 $\mathrm{km}^{2}$ in 9 counties in northwest and central Washington, including Clallam and Jefferson counties on the Olympic Pennisula. The region includes the North Pacific Coastal and Columbia Glaciated freshwater ecoregions with a variety of temperate coastal streams, rivers, wall seeps, and ponds/lakes (Abell et al. 2000). The North Pacific Coastal region includes mesic landscapes on the west side of the North Cascade Range and a drier Columbia Glaciated region east of the Cascade Range. The study area also encompassed 5 physiographic regions including the Olympic Mountains, Puget Lowland, Northern Cascades, Okanogan West, and Columbia Basin (Rosenfeld 1985).

These landscapes contain a number of urban communities with a combined total of over 300,000 residents (United States Census Bureau 2013). Bellingham is the largest urban center with over 80,000 residents; most other urban centers have $<10,000$ residents (Blinn and Ruiter 2013). Dairy, corn, and berry farming make up a large portion of the agriculture in the lowland landscapes on the west side of the Cascade Range, while dryland crops and rangelands are common on the east side of 
the Cascade Range (personal observation). The urban and agricultural landscapes west of the Cascades are typically $<300 \mathrm{~m}$ in elevation, and most forest landscapes range from 300 to $2000 \mathrm{~m}$. In contrast, agricultural landscapes east of the Cascade range are typically $>300 \mathrm{~m}$. Average elevation for the study area on the western side of the Cascade Range was $226 \mathrm{~m}$ (SE 27), while study areas east of the range averaged $638 \mathrm{~m}$ (SE 30).

Riparian vegetation in urban landscapes includes Acer macrophyllum, Alnus rubra, and Pseudotsuga menziesii, while agricultural landscapes include grasses, sedges, and A. rubra. Riparian vegetation along lowland forest sites contain A. macrophyllum, A. rubra, Salix scouleriana, Salix sitchensis, P. menziesii, and Populus balsamifera ssp. trichocarpa, which is largely replaced by Tsuga heterophylla and Thuja plicata in lowland riparian systems (Blinn and Ruiter 2013). Picea sitchensis is also present along the streams in the lowlands on the Olympic Pennisula. Riparian vegetation in drier eastern Washington includes P. menziesii, Pinus ponderosa, and dry grassland vegetation (personal observation).

\section{Methods}

Diatoms were collected from 99 streams, 41 rivers, 9 wall seeps (water running down rock faces), and 16 ponds/lakes based on access during mid-June through September from 2008 through 2012 in northwest and north central Washington, including the Olympic Pennisula (Appendix 1). Diatoms were collected by scraping algal material from an approximate $3 \times 3-\mathrm{cm}$ area from rock and sediment substrates and by collecting submerged leaves and moss at all sites. The diatom floras by Krammer and Lange-Bertalot (1986, 1988, 1991a, 1991b, 2000) were routinely used for the identification of species.

Land use (urban, agriculture, forest) was noted and physicochemical information was collected at each site. Agricultural regions included cornfields and livestock pastures with cattle and horses; urban areas had $\geq 1000$ residents; and forested land contained $>50 \%$ tree cover. Maximum water temperatures were measured with a handheld thermometer on-site. Specific conductance (at $25{ }^{\circ} \mathrm{C}$ ) of water was determined with a conductance meter (Radiometer, Copenhagen, Denmark;
Model CDM2e) in the laboratory, and $\mathrm{pH}$ was measured with an Oakton pH 6 meter onsite. Channel embeddedness was determined to the nearest $5 \%$ interval at each site following Platts et al. (1983). Suspended sediments were determined according to MacDonald et al. (1991), and canopy cover was determined with a spherical densiometer (Forest Densiometer Model A) to the nearest 5\% interval.

Water collections for TN and TP were immediately placed on dry ice and analyzed within 14 days by the persulfate digestion and flow injection method on an FS3000 Flow Injection Analyzer made by OI Corporation (APHA 2005). The digestion method was an alkaline oxidation (APHA 4500-PJ) using sodium hydroxide and potassium persulfate. Following the digestion, TP was measured using the ascorbic acid method (APHA $4500-\mathrm{PH}$ ) and $\mathrm{TN}$ was measured using the cadmium reduction method on the FS3000 (APHA 4500 NO3-I).

Kendall's tau $(\tau)$ rank correlation coefficients were calculated between species richness and TN, TP, specific conductance, altitude, maximum water temperature, $\mathrm{pH}$, and percent canopy. Principal components analysis was used based on singular value decomposition of the centered, scaled data matrix to extract the important relationships among water quality and diatom variables (Jongman et al. 1995, Ben-Hur and Guyon 2003, R Development Core Team 2011). Principal components were used as new variables to identify stable clusters using hierarchical clustering with Euclidean distance and Ward's minimum variance cluster method, following the methods outlined by Ben-Hur and Guyon (2003). Rare species were included in the analyses. The PCA variables were centered on the mean and scaled to unit variance. Shannon's diversity index was also calculated for diatom assemblages at each site.

A tolerance index was used for channel embeddedness, TN, TP, and specific conductance to compare the distribution of diatom species along each of these environmental gradients. The following equation was developed by Blinn (1993) for specific conductance (SCI) to examine the distribution of diatoms in salt lakes in western USA and expanded by Blinn and Ruiter (2006, 2013) for caddisflies: 
$\mathrm{SCI}_{x}=\frac{\sum_{x}^{N_{x}}\left[\log _{10}\left(R A_{\mathrm{i}} \cdot 100\right)\right](\text { Specific Conductance, } \mu \mathrm{S} / \mathrm{cm})}{N_{x}}$,

where $R A=$ relative abundance (percent) of species $x$ at a given stream site, and $N=$ number of streams in which species $x$ occurred. The diatom tolerance index (DTI) is a summation of the adjusted combined numeric values of total nitrogen index (TNI), total phosphorus index (TPI), specific conductance index (SCI), and embedded index (EMBI). Elevated nutrients, salinization of water, and siltation of cobbles are 3 of the most influential stressors for stream biota (Laws 2000, Enger and Smith 2009). We adjusted the DTI numeric scores to a 0-10 scale for comparison.

\section{RESULTS}

Diatom Distribution and Physicochemical Features

Four hundred and fifteen diatom species were identified from streams, rivers, wall seeps and pond/lake sites in northwest and north central Washington (Appendix 2). Three hundred and fifty-two species were collected from streams/rivers, 87 species from wall seeps, and 213 species from ponds/lakes.

Aquatic systems sampled west of the Cascade Range averaged $278 \mathrm{~m}$ (SE 30.5) in altitude, while those east of the Cascade Range averaged $855 \mathrm{~m}$ (SE 68.3). $\mathrm{H}^{\prime}$ ranged from 1.57 to 5.06 west of the Cascades, and from 1.85 to 4.98 east of the Cascade Range. Nearly 77\% of the taxa were either mono- or biraphid diatoms. Species richness averaged 30.5 (SE 1.3) per site on the west side of the Cascades and 43 (SE 2.8) on the east side. Achnanthidium minutissimum, Cocconeis placentula f. lineata, Diatoma mesodon, Encyonema silesiacum, Eunotia bilunaris, Fragilaria capucina, Fragilaria vaucheria, Frustulia vulgaris, Gomphonema parvulum, Meridion circulare, Nitzschia dissipata, Planothidium lanceolatum, and Ulnaria ulna occurred in over $50 \%$ of the sites examined throughout the study area.

Ponds and lakes had the highest average number of species at 42.2 (SE 3.2) per site (Fig. 1). $\mathrm{H}^{\prime}$ diversity for these habitats at lower elevations $(<700 \mathrm{~m})$ ranged from 2.83 to 4.77 with an average of 34 (SE 2) species, while those at higher elevations $(>1150 \mathrm{~m})$ ranged from 3.53 to 5.19 with an average of 56 (SE 7) species. Achnanthidium minutissimum, C. placentula v. lineata, E. bilunaris, F. capucina, F. vaucheria, U. ulna, Gomphonema truncatum, and Staurosira construens f. venter were common in low-elevation ponds and lakes, while A. minutissimum, Aulacoseira alpigena, D. mesodon, Eunotia spp., Frustulia spp., Pinnularia spp., and Tabellaria floculossa were common taxa in high-elevation lakes.

Urban streams and rivers averaged 38 (SE 2.6) species compared to 33 (SE 2.1) species in agricultural landscapes, and 26 species (SE 1.9) in forest landscapes (Fig. 1). Cocconeis placentula v. lineata, F. capucina, P. lanceolatum, U. ulna, and Rhoicosphenia abbreviatum were common species in urban streams, while Melosira varians, $N$. dissipata, Nitzschia linearis, Nitzschia palea, and U.ulna were common taxa in lowland agricultural streams and rivers. $\mathrm{H}^{\prime}$ diversity ranged from 2.98 to 4.92 for urban streams and from 3.33 to 5.04 for lowland agricultural streams. Aulacoseira alpigena, Diatoma hyemalis, D. mesodon, Eunotia spp., Hannaea arcus, M. circulare, Pinnularia divergens, and T. flocculosa were common in streams and rivers at higher elevations $(>700 \mathrm{~m})$ on both sides of the Cascades. $\mathrm{H}^{\prime}$ diversity in high-elevation streams ranged from 2.45 to 4.27 on the west side of the Cascades and from 2.90 to 4.98 on the east side. Wall seeps had the lowest average number of species (18, SE 2.1) with $\mathrm{H}^{\prime}$ ranging from 1.57 to 2.99. Diatoma mesodon, D. hyemalis, Diatomella balfourinia, F. capucina, F. vaucheria, Eunotia spp., T. flocculosa, Tetracyclus glans, and Tetracyclus rupestris were common assemblages in wall seeps.

$\mathrm{pH}$ ranged from 6.6 to 8.3 , with a mode of 7.1 throughout the study area. Average TN was nearly 6 -fold higher on the west side of the Cascades compared to the east side (Table 1). TN and TP values for streams west of the Cascades were $725 \mu \mathrm{g} \cdot \mathrm{L}^{-1}$ (SE 122) and 18.5 $\mu \mathrm{g} \cdot \mathrm{L}^{-1}$ (SE 3.8) compared to $88.7 \mu \mathrm{g} \cdot \mathrm{L}^{-1}$ (SE 21.7) and $21.7 \mu \mathrm{g} \cdot \mathrm{L}^{-1}$ (SE 5.3) east of the Cascades. Lowland sites in the agricultural region west of the Cascades had the highest average TN (1673 $\mu \mathrm{g} \cdot \mathrm{L}^{-1}$, SE 349) and TP levels $\left(63.5 \mu \mathrm{g} \cdot \mathrm{L}^{-1}, \mathrm{SE} 21\right)$ and the highest average specific conductance $(2.75$ $\mathrm{mS} \cdot \mathrm{cm}^{-1}$, SE 2.3). Channel embeddedness averaged $85 \%$ (SE 7.1). Average TN and TP values for rivers west of the Cascades were $101.5 \mu \mathrm{g} \cdot \mathrm{L}^{-1}(\mathrm{SE} 12.6)$ and $18.9 \mu \mathrm{g} \cdot \mathrm{L}^{-1}(\mathrm{SE}$ 3.5), respectively, compared to $115.7 \mu \mathrm{g} \cdot \mathrm{L}^{-1}$ 


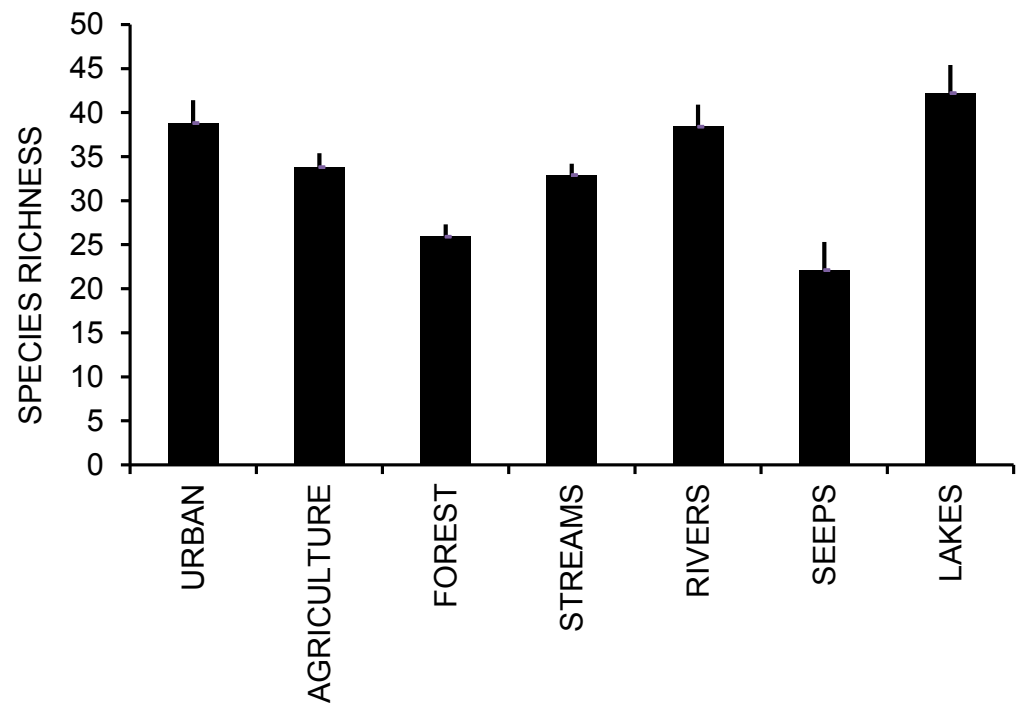

Fig. 1. Mean diatom species richness for land use and habitats in northwest and north central Washington.

TABLE 1. Average values (standard errors in parentheses) for physicochemical features of aquatic systems on the west and east sides of the North Cascade Mountain Range.

\begin{tabular}{lcc}
\hline Physicochemical feature & West & East \\
\hline Altitude $(\mathrm{m})$ & $278(30.5)$ & $855(68.3)$ \\
Total phosphorus $\left(\mu \mathrm{g} \cdot \mathrm{L}^{-1}\right)$ & $20.5(3)$ & $16.2(2.5)$ \\
Total nitrogen $\left(\mu \mathrm{g} \cdot \mathrm{L}^{-1}\right)$ & $452(79)$ & $80.2(11.2)$ \\
Specific conductance $\left(\mathrm{mS} \cdot \mathrm{cm}^{-1}\right)$ & $0.379(0.254)$ & $0.122(0.02)$ \\
Canopy cover $(\%)$ & $47(3.6)$ & $38(6)$ \\
Embeddedness $(\%)$ & $35(3.1)$ & $16.8(3.5)$ \\
\hline
\end{tabular}

TABLE 2. Kendall's $\tau$ rank-based correlations between diatom species richness and environmental determinants.

\begin{tabular}{lc}
\hline & Kendall's $\tau$ \\
\hline Altitude & -0.050 \\
Specific conductance** & 0.146 \\
Maximum water temperature** & 0.171 \\
Total phosphorus** & 0.210 \\
Total nitrogen* & 0.106 \\
pH** & 0.156 \\
$\%$ Canopy cover* & -0.136 \\
Channel embeddedness*** & 0.213 \\
\hline$* P \leq 0.05$ & \\
$* * P \leq 0.01$ &
\end{tabular}

(SE 21.7) and $18.3 \mu \mathrm{g} \cdot \mathrm{L}^{-1}(\mathrm{SE} 3)$ east of the Cascades.

Diatom species richness showed significant positive correlations to channel embeddedness, TN, TP, specific conductivity, maximum water temperature, and $\mathrm{pH}$, and a significant negative correlation to percent canopy cover (Table 2 ). More detailed information on physicochemi- cal features between landscapes (urban, agriculture, forest) and habitats (stream, river, seep, pond/lake) in the study area can be found in Blinn and Ruiter (2013).

Hierarchical clustering produced 6 stable cluster groups using the first 3 principal components as clustering variables (Fig 2, Table 3 ). These cluster groups appeared to match natural groups formed by geographic location and landuse type. A simple chi-square contingency table showed a significant association between the 6 "blind" hierarchical cluster groups and the following location/land-use groups (Crawley 2007).

Cluster A included 7 stream, 10 river, and 11 pond/lake sites primarily west of the Cascade Range at an average altitude of $88 \mathrm{~m}$ (SE 19), a canopy cover of $8.3 \%$ (SE 2), and a channel embeddedness of 92\% (SE 1.0) (Table 3). These sites were primarily located in the lowland agricultural region (berry, dairy, and corn) west of the Cascades in Whatcom County. The only sites east of the Cascade Range included 


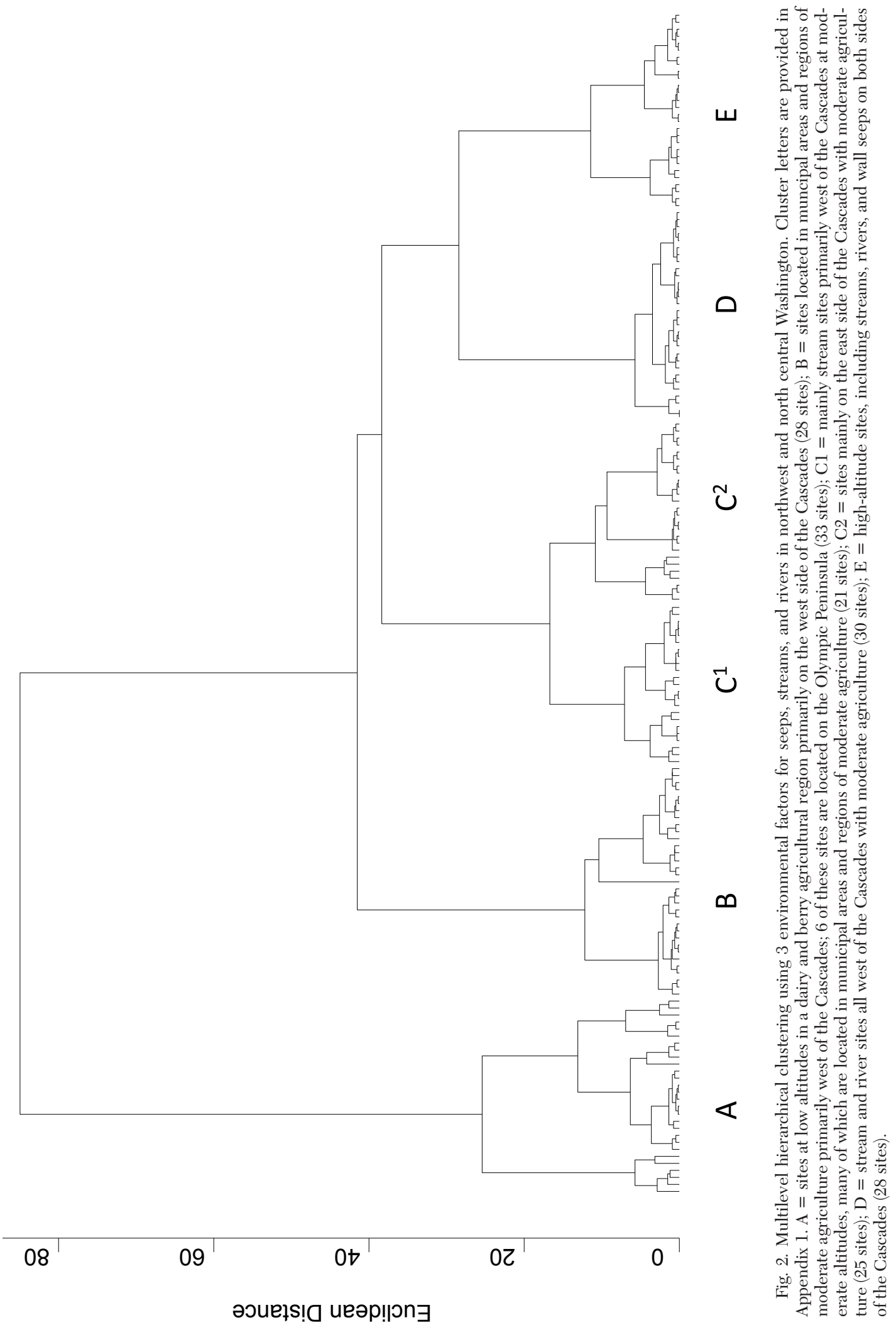


TABLE 3. Average values (standard errors in parentheses) for physicochemical features of the 6 hierarchial cluster groups for aquatic habitats in western Washington.

\begin{tabular}{lcccccc}
\hline & \multicolumn{7}{c}{ Cluster group } \\
\cline { 2 - 6 } Physicochemical feature & $\mathrm{A}$ & $\mathrm{B}$ & $\mathrm{C} 1$ & $\mathrm{C} 2$ & $\mathrm{D}$ & $\mathrm{E}$ \\
\hline Altitude $(\mathrm{m})$ & 88 & 337 & 169 & 487 & 208 & 850 \\
& $(19)$ & $(69)$ & $(51)$ & $(42)$ & $(27)$ & $(64)$ \\
Total phosphorus $\left(\mu \mathrm{g} \cdot \mathrm{L}^{-1}\right)$ & 48 & 129 & 20 & 8.8 & 13.9 & 7.1 \\
& $(10)$ & $(25)$ & $(3.6)$ & $(1.2)$ & $(2.3)$ & $(1.2)$ \\
Total nitrogen $\left(\mu \mathrm{g} \cdot \mathrm{L}^{-1}\right)$ & 898 & 138 & 526 & 90 & 285 & 60 \\
Specific conductance $\left(\mathrm{mS} \cdot \mathrm{cm}^{-1}\right)$ & $(196)$ & $(21)$ & $(69)$ & $(16)$ & $(51)$ & $(8.2)$ \\
& $(0.9)$ & $(0.01)$ & $(0.174$ & 0.09 & 0.109 & 0.07 \\
\% Canopy cover & 8.3 & 18.6 & 76 & $(0.01)$ & $(0.03)$ & $(0.01)$ \\
& $(2)$ & $(3.1)$ & $(6)$ & 54 & 85 & 39 \\
\% Embeddedness & 92 & 55 & 18.5 & 12.2 & $(2.9)$ & $(7.2)$ \\
Temperature $\left({ }^{\circ} \mathrm{C}\right)$ & $(1)$ & $(6.2)$ & $(2.6)$ & $(1.7)$ & $(1.5)$ & $(0.8)$ \\
& 21 & 16.3 & 18.2 & 16.6 & 16 & 14.1 \\
& $(0.6)$ & $(0.3)$ & $(0.5)$ & $(0.4)$ & $(0.2)$ & $(0.2)$ \\
\hline
\end{tabular}

the Columbia and Okanogan rivers. TN and TP averaged $898 \mu \mathrm{g} \cdot \mathrm{L}^{-1}$ (SE 196) and $48 \mu \mathrm{g} \cdot$ $\mathrm{L}^{-1}$ (SE 10), respectively, for sites in this cluster. These sites had the lowest average altitude and the highest average channel embeddedness, TN, specific conductance, and water temperature of all sites examined.

Cluster B included 7 stream, 20 river, and 6 pond/lake sites at an average altitude of 337 $\mathrm{m}$ (SE 69) and a canopy cover of $18.6 \%$ (SE 3.1). This cluster included 30 sites west and 3 sites east of the Cascades. Six river and stream sites were located on the Olympic Peninsula. $\mathrm{TN}$ and TP averaged $138 \mu \mathrm{g} \cdot \mathrm{L}^{-1}(\mathrm{SE} 21)$ and $19.8 \mu \mathrm{g} \cdot \mathrm{L}^{-1}$ (SE 3), respectively. Average water temperature and specific conductance for sites in this cluster were $16.3{ }^{\circ} \mathrm{C}$ (SE 0.3) and $0.08 \mathrm{mS} \cdot \mathrm{cm}^{-1}$ (SE 0.01), respectively. This cluster had one of the lowest average specific conductance values.

Cluster $\mathrm{C} 1$ included 21 stream and 2 river sites located at an average altitude of $169 \mathrm{~m}$ (SE 51) and a canopy cover of 76\% (SE 6). Nineteen sites were located on the east side of the Cascades. TP averaged $526 \mu \mathrm{g} \cdot \mathrm{L}^{-1}$ (SE 69) for sites on the west side and $20 \mu \mathrm{g}$. $\mathrm{L}^{-1}$ (SE 3.6) east of the Cascades. Average water temperature and specific conductance were $18.2{ }^{\circ} \mathrm{C}(\mathrm{SE} 0.5)$ and $0.174 \mathrm{mS} \cdot \mathrm{cm}^{-1}$ (SE 0.01). Many of these sites were located in small municipal regions or areas with moderate agriculture. Cluster C2 included 17 stream and 9 river sites at moderate altitudes (487 m, SE 42) and canopy cover $(54 \%, \mathrm{SE} 7)$. Seventeen sites were located on the east side of the Cascades.
Average water temperatures and embeddedness were similar to $\mathrm{Cl}$ sites west of the Cascades, while average specific conductance, $\mathrm{TN}$, and TP were considerably lower (Table 3).

Cluster D included a total of 30 stream and river sites, all west of the Cascades with 3 sites on the Olympic Peninsula. The average altitude of these sites was $208 \mathrm{~m}$ (SE 27) with a canopy cover of 85\% (SE 2.9). TN and TP averaged $285 \mu \mathrm{g} \cdot \mathrm{L}^{-1}$ (SE 51) and $13.9 \mu \mathrm{g} \cdot \mathrm{L}^{-1}$ (SE 2.3), and specific conductance averaged $0.109 \mathrm{mS} \cdot \mathrm{cm}^{-1}$ (SE 0.03).

Cluster E included 28 high-altitude $(850 \mathrm{~m}$; SE 64), cool water $\left(14.1^{\circ} \mathrm{C}\right.$; SE 0.2$)$ streams, rivers, and wall seeps. This included 20 sites west and 8 sites east of the Cascade Range. $\mathrm{TN}$ and TP averaged $60 \mu \mathrm{g} \cdot \mathrm{L}^{-1}(\mathrm{SE} 1.2)$ and $7.1 \mu \mathrm{g} \cdot \mathrm{L}^{-1}$ (SE 1.2), while specific conductance averaged $0.07 \mathrm{mS} \cdot \mathrm{cm}^{-1}$ (SE 0.01). Sites in this cluster had the highest average altitude and lowest average water temperature, specific conductance, TN, TP, and channel embeddedness of any cluster (Table 3).

The invasive alga Didymosphenia geminata was collected in $46 \%$ of the stream and river sites sampled and ranged from $<1 \%$ to $27 \%$ in relative abundance, but was not collected in ponds/lakes or wall seeps. Didymosphenia geminata showed significant $(P=0.05)$ negative correlations to altitude $(r=-0.138)$ and TN $(r=-0.127)$ and a significant positive correlation $(0.319)$ to suspended sediment. The average relative abundance of $D$. geminata was $2.2 \%$ (SE 0.6) in streams compared to 4.7\% (SE 2.1) in rivers. Didymosphenia geminata was collected 


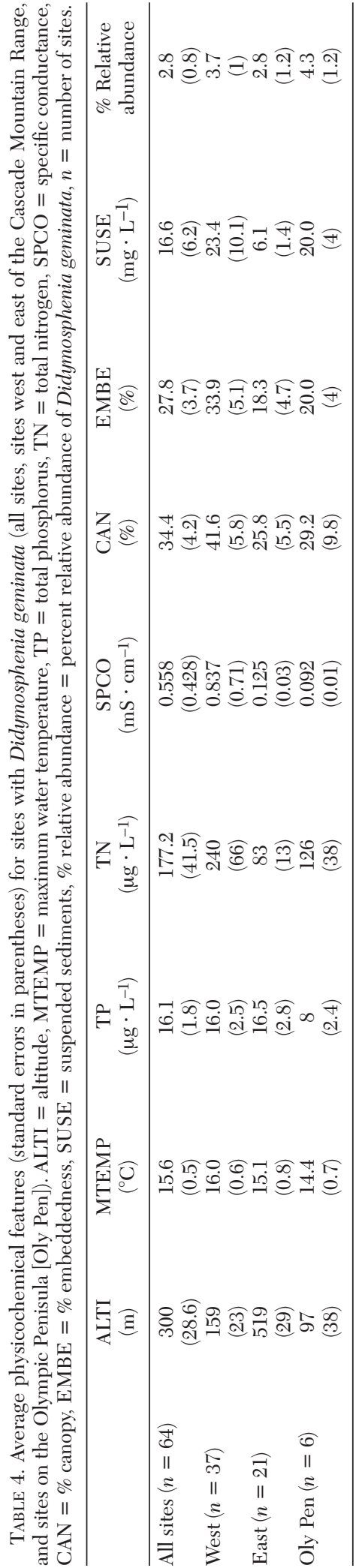

in $87 \%$ of the river sites examined on the mainland and all river sites on the Olympic Peninsula except the Elwa River. This invasive alga was present throughout the main channel of the Nooksack River, including the north, middle, and south forks (Appendix 1). In contrast, D. geminata was only collected in $33 \%$ of the stream sites examined.

Average physicochemical features of habitats throughout the study area with $D$. geminata, including the Olympic Penisula, are presented in Table 4. The average $\mathrm{TN}$ was 134 $\mu \mathrm{g} \cdot \mathrm{L}^{-1}$ (SE 35) in streams compared to $93 \mu \mathrm{g} \cdot$ $\mathrm{L}^{-1}$ (SE 7.9) in rivers. Also, specific conductance in streams with $D$. geminata averaged $0.08 \mathrm{mS} \cdot \mathrm{cm}^{-1}$ (SE 0.02$)$ compared to $3 \mathrm{mS} \cdot$ $\mathrm{cm}^{-1}$ (SE 1.9) in rivers. Average water temperature for D. geminata on the Olympic Peninsula was $14.4^{\circ} \mathrm{C}(\mathrm{SE} 0.7 ; n=5)$ compared to $17^{\circ} \mathrm{C}$ (SE $0.3 ; n=59)$ on the mainland. Average water temperature for aquatic systems with this alga throughout the study area was $15.6{ }^{\circ} \mathrm{C}$ (SE $0.5 ; n=64)$.

The average $\mathrm{TN}$ for rivers with $D$. geminata was $98.4 \mu \mathrm{g} \cdot \mathrm{L}^{-1}$ (SE 10.7) compared to 491 $\mu \mathrm{g} \cdot \mathrm{L}^{-1}$ (SE 131) for those without this alga. Stream sites with $D$. geminata had a TN value of $131.4 \mu \mathrm{g} \cdot \mathrm{L}^{-1}$ (SE 23.6) compared to 838.3 $\mu \mathrm{g} \cdot \mathrm{L}^{-1}$ (SE 182) for those without D. geminata. All sites with this alga had an average TN value of $127 \mu \mathrm{g} \cdot \mathrm{L}^{-1}$ (SE 19.4), while sites without this alga had an average $\mathrm{TN}$ value of $788 \mathrm{mg} \cdot \mathrm{L}^{-1}$ (SE 163). The average relative frequency of $D$. geminata was $2.2 \%$ (SE 0.6) in streams compared to $4.7 \%$ (SE 2.1) in rivers.

The average relative abundance of $D$. geminata in habitats west of the Cascades was $3.7 \%$ (SE $1 ; n=37)$ compared to $2.8 \%(\mathrm{SE} 1.2 ; n=$ 22 ) on the east side. The relative abundance of $D$. geminata on the Olympic Pennisula was 4.3\% (SE 1.2). Average TP and TN concentrations for all sites with $D$. geminata throughout the study area were $16.1 \mu \mathrm{g} \cdot \mathrm{L}^{-1}$ (SE 1.8) and $177.2 \mu \mathrm{g} \cdot \mathrm{L}^{-1}$ (SE 41.5), respectively. Highest TN value for streams with $D$. geminata was $408 \mu \mathrm{g} \cdot \mathrm{L}^{-1}$ in Thompson Creek compared to $278 \mu \mathrm{g} \cdot \mathrm{L}^{-1}$ in the Calawah River for river systems. Fifty-five percent of the sites with $D$. geminata had TP values $\leq 10 \mu \mathrm{g} \cdot \mathrm{L}^{-1}$, while $53 \%$ had $\mathrm{TN}$ values $\leq 100 \mu \mathrm{g} \cdot \mathrm{L}^{-1}$. Mean TP and TN for streams with $D$. geminata west of the Cascades was 10.1 (SE 1.9) and $154.8 \mu \mathrm{g} \cdot$ $\mathrm{L}^{-1}$ (SE 21.8), respectively, compared to 9.7 
(SE 2.8) and 52.4 (SE 16.4) $\mu \mathrm{g} \cdot \mathrm{L}^{-1}$ east of the Cascades. D. geminata made up 5.4\% (SE 1.2) of the diatom assemblage in streams and rivers with $\geq 5 \mathrm{mg} \cdot \mathrm{L}^{-1}$ suspended sediment, compared to $2.2 \%$ (SE 0.4 ) for those with $<5 \mathrm{mg}$. $\mathrm{L}^{-1}$ suspended sediment. Other physicochemical features for habitats with $D$. geminata are provided in Table 4.

\section{Diatom Tolerance Values}

A diatom tolerance index (DTI) for channel embeddedness (EMBI), nutrients (TNI, TPI), and specific conductance (SCI) is provided in Table 5 for 114 of the most common diatom taxa in the region. The percent relative frequency for each species throughout the study area is also provided. The adjusted DTI values (ADJUS) ranged from 0 to 10 . Tolerance values $\leq 4.0$ are considered more sensitive to the measured environmental parameters, while tolerance values $\geq 6.0$ are considered more tolerant.

The majority of taxa with DTI values $\leq 4.0$ were either araphid or monoraphid (e.g., Aulacoserira alpigena, Diatomella balfourniana, Eunotia paludosa, Gomphonema affine, Orthoseira dendroteres, and Tetracyclus glans, etc.), and occurred on hard substrata with limited motility. These taxa were common in the higheraltitude sites. In contrast, $55 \%$ of the species with DTI values $\geq 6.0$ were keeled or canalraphed taxa (e.g., Cymatopleura solea, Nitzschia amphibia, $N$. dissipata, $N$. linearis, $N$. palea, and Surirella ovalis, etc.) and occurred in habitats with elevated embeddedness and nutrients in stream channels throughout the study area.

Genera, which included species with active movement (Navicula, Nitzschia, and Surirella), made up $<10 \%$ of the taxa with ADJUS values $\leq 4.0$, while species in these genera made up over $70 \%$ of taxa with ADJUS values $\geq 6.0$. Achnanthidium minutissimum, C. placentula f. lineata, D. mesodon, E. silesiacum, F. capucina, F. vaucheria, F. vulgaris, G. parvulum, P. lanceolatum, $N$. dissipata, and $U$. ulna occurred in over $50 \%$ of the sites with WADJUS values ranging from 4.6 to 6.4. Araphid, monoraphid, and centric diatoms typically had lower EMBI values, which implied species associated with vegetation and hard surface substrates. Biraphid diatoms were more common along increasing EMBI values which suggested habitats with fine sediments.

\section{Discussion}

Diatom species richness declined as stream channel conditions deteriorated throughout the Washington landscape. Cooke and Prepas (1998) reported that crop fertilizers and animal manure constituted a large portion of nonpoint-source pollution of phosphorus and nitrogen in streams. Also, Lee and Ziegler (2010) found that urbanization, construction activity, and impoundments influence rates of embeddedness and salinity in streams, while Kauffman and Krueger (1984) reported livestock impacts on riparian ecosystems. These conditions also influenced both composition and species richness in diatom communities throughout the Washington landscape. Fore and Grafe (2002) developed a river diatom index (RDI) for Idaho rivers and found it to be significantly correlated with human disturbance at the site (i.e., conductivity, percentage of fine sediments, and number of human activities) and at the catchment level (i.e., percentage of urbanization and agriculture in the upstream catchment).

The hierarchial clustering model indicated that diatoms were useful environmental indicators of both land use and altitudinal gradients in Washington aquatic ecosystems. The model separated diatom assemblages into distinct clusters that ranged from lowland aquatic habitats with heavy crop and dairy farming to those with low to moderate agriculture activity at moderate to high altitudes west of the Cascades. The model also separated diatom communities located west and east of the Cascades. Use of dominant diatom taxa associated with low and highly disturbed habitats provides a useful monitoring program for the region.

DTI values for embeddedness, nutrients, and salinity for each species enhanced the ability to determine which environmental parameter(s) are responsible for conditions in the stream systems in the Washington landscape. Diatom species showed distinct associations with physicochemical conditions in aquatic habitats throughout the study area. The majority of taxa with DTI values $\leq 4.0$ were either araphid, monoraphid, or biraphid, and their presence suggested hard substrata and limited motility. These taxa were common in the higher-altitude sites.

In contrast, $55 \%$ of the species with DTI values $\geq 6.0$ were keeled or canal-raphed taxa, 
TABLE 5. Diatom tolerance index (DTI) for 114 species collected in Washington. Ranking of diatom taxa is based on combined tolerance values for channel embeddedness (EMBI), total phosphorus (TPI), total nitrogen (TNI), and specific conductance (SCI). Combined tolerance values (ADJUS) were adjusted to a scale of 0 to 10 . Species were arranged from most sensitive to most tolerant based on combined tolerance values. \% Relative frequency $=$ percentage of sites in which species occurred throughout the study area.

\begin{tabular}{|c|c|c|c|c|c|c|c|}
\hline Diatom species & EMBI & TPI & TNI & SCI & DTI & ADJUS & $\begin{array}{l}\% \text { Relative } \\
\text { frequency }\end{array}$ \\
\hline Diatomella balfourniana & 21 & 2 & 38 & 101 & 162 & 0.8 & 11.0 \\
\hline Orthoseira dendroteres & 11 & 20 & 52 & 84 & 167 & 0.8 & 1.2 \\
\hline Tetracyclus rupestris & 15 & 23 & 81 & 88 & 207 & 1.0 & 4.5 \\
\hline Rossithidium nodosum & 17 & 23 & 87 & 139 & 266 & 1.3 & 4.5 \\
\hline Orthoseira roeseana & 42 & 12 & 91 & 123 & 268 & 1.3 & 2.5 \\
\hline Epithemia argus & 14 & 11 & 125 & 120 & 270 & 1.4 & 4.0 \\
\hline Pinnularia borealis & 48 & 12 & 204 & 142 & 406 & 2.0 & 5.0 \\
\hline Tetracyclus glans & 43 & 17 & 203 & 149 & 412 & 2.1 & 3.2 \\
\hline Aulacoseira alpigena & 44 & 18 & 243 & 152 & 457 & 2.3 & 7.6 \\
\hline Surirella linearis & 25 & 40 & 228 & 165 & 458 & 2.3 & 5.7 \\
\hline Eunotia soleirolii & 54 & 24 & 272 & 113 & 463 & 2.3 & 8.9 \\
\hline Pinnularia subcapitata & 59 & 14 & 317 & 86 & 476 & 2.4 & 5.4 \\
\hline Epithemia adnata & 31 & 49 & 199 & 236 & 515 & 2.6 & 4.5 \\
\hline Caloneis tenuis & 62 & 15 & 263 & 182 & 522 & 2.6 & 4.5 \\
\hline Nitzschia angustata & 73 & 26 & 209 & 253 & 561 & 2.3 & 3.8 \\
\hline Rossithidium petersennii & 35 & 27 & 349 & 177 & 588 & 2.9 & 6.4 \\
\hline Diatoma anceps & 54 & 21 & 341 & 175 & 591 & 3.0 & 5.7 \\
\hline Eunotia paludosa & 66 & 37 & 330 & 164 & 597 & 3.0 & 13.3 \\
\hline Tabellaria flocculosa & 72 & 25 & 348 & 153 & 598 & 3.0 & 34.4 \\
\hline Diatoma hyemalis & 58 & 29 & 333 & 184 & 604 & 3.0 & 17.8 \\
\hline Fragilaria virescens & 77 & 18 & 431 & 89 & 615 & 3.1 & 5.1 \\
\hline Gomphonema affine & 32 & 16 & 411 & 184 & 643 & 3.2 & 6.4 \\
\hline Aulacoseira distans & 65 & 9 & 470 & 113 & 657 & 3.3 & 3.9 \\
\hline Eunotia monodon & 62 & 25 & 450 & 150 & 687 & 3.4 & 3.2 \\
\hline Psammothidium subatomoides & 45 & 22 & 475 & 150 & 692 & 3.5 & 28.6 \\
\hline Didymosphenia geminata & 73 & 28 & 406 & 200 & 707 & 3.5 & 2.6 \\
\hline Hannaea arcus & 63 & 35 & 404 & 211 & 713 & 3.6 & 49.2 \\
\hline Caloneis alpestris & 68 & 22 & 376 & 258 & 724 & 3.6 & 5.5 \\
\hline Rhopalodia gibba & 67 & 39 & 407 & 226 & 739 & 3.7 & 15.9 \\
\hline Achnanthidium exile & 67 & 31 & 464 & 178 & 740 & 3.7 & 10.8 \\
\hline Gomphonema olivaceum & 51 & 26 & 486 & 180 & 743 & 3.7 & 16.5 \\
\hline Eucocconeis laevis & 45 & 24 & 467 & 211 & 747 & 3.7 & 7.0 \\
\hline Diploneis oblongella & 24 & 23 & 494 & 219 & 760 & 3.8 & 3.8 \\
\hline Tabellaria fenestrata & 67 & 51 & 395 & 249 & 762 & 3.8 & 5.1 \\
\hline Diatoma vulgaris & 43 & 34 & 486 & 227 & 790 & 4.0 & 24.2 \\
\hline Cymbella affinis & 56 & 29 & 501 & 206 & 792 & 4.0 & 49.7 \\
\hline Caloneis schumanniana & 29 & 20 & 549 & 223 & 821 & 4.1 & 5.5 \\
\hline Amphipleura pellucida & 43 & 37 & 537 & 237 & 854 & 4.3 & 7.6 \\
\hline Navicula margalithii & 54 & 43 & 493 & 267 & 857 & 4.3 & 6.3 \\
\hline Gomphonema truncatum & 61 & 36 & 517 & 248 & 862 & 4.3 & 19.1 \\
\hline Caloneis silicula & 56 & 24 & 620 & 163 & 863 & 4.3 & 11.5 \\
\hline Eunotia pectinalis v. undulata & 61 & 33 & 586 & 199 & 879 & 4.4 & 23.0 \\
\hline Brachysira brebissonii & 65 & 33 & 627 & 165 & 890 & 4.5 & 5.7 \\
\hline Navicula recens & 55 & 24 & 620 & 204 & 903 & 4.5 & 11.5 \\
\hline Diatoma mesodon & 56 & 33 & 584 & 239 & 912 & 4.6 & 62.0 \\
\hline Sellaphora pupula & 76 & 58 & 528 & 256 & 918 & 4.6 & 11.4 \\
\hline Gomphonema acuminatum & 57 & 29 & 587 & 246 & 919 & 4.6 & 21.6 \\
\hline Hantzschia amphioxys & 49 & 51 & 589 & 232 & 921 & 3.6 & 11.5 \\
\hline Caloneis sublinearis & 61 & 30 & 693 & 151 & 935 & 4.7 & 2.5 \\
\hline Aulacoseira italica & 84 & 48 & 549 & 261 & 942 & 4.7 & 9.5 \\
\hline Encyonema minutum & 69 & 35 & 628 & 214 & 946 & 4.7 & 24.0 \\
\hline Reimeria sinuata & 49 & 31 & 656 & 215 & 951 & 4.8 & 47.0 \\
\hline Fragilaria vaucheriae & 67 & 35 & 606 & 243 & 951 & 4.8 & 65.7 \\
\hline Encyonopsis microcephala & 69 & 35 & 638 & 212 & 954 & 4.8 & 26.8 \\
\hline Navicula radiosa & 65 & 46 & 627 & 224 & 962 & 4.8 & 12.0 \\
\hline Psammothidium bioretii & 69 & 28 & 651 & 226 & 974 & 4.9 & 9.5 \\
\hline Achnanthidium minutissimum & 65 & 44 & 599 & 266 & 974 & 4.9 & 68.0 \\
\hline Pinnularia divergens & 54 & 40 & 701 & 181 & 976 & 4.9 & 33.7 \\
\hline
\end{tabular}


TABLE 5. Continued.

\begin{tabular}{|c|c|c|c|c|c|c|c|}
\hline Diatom species & EMBI & TPI & TNI & SCI & DTI & ADJUS & $\begin{array}{l}\% \text { Relative } \\
\text { frequency }\end{array}$ \\
\hline Navicula recens & 58 & 25 & 684 & 212 & 979 & 4.9 & 11.5 \\
\hline Encyonema silesiacum & 72 & 41 & 633 & 244 & 990 & 5.0 & 64.7 \\
\hline Fragilaria tenera & 51 & 34 & 688 & 221 & 994 & 5.0 & 14.6 \\
\hline Eunotia bilunaris & 70 & 28 & 648 & 250 & 996 & 5.0 & 38.0 \\
\hline Amphora pediculus & 42 & 40 & 675 & 253 & 1010 & 5.1 & 21.0 \\
\hline Epithemia sorex & 61 & 33 & 688 & 236 & 1018 & 5.1 & 9.5 \\
\hline Diatoma tenuis & 63 & 30 & 693 & 233 & 1019 & 5.1 & 16.5 \\
\hline Nitzschia sigma & 76 & 24 & 723 & 197 & 1020 & 5.1 & 9.6 \\
\hline Nitzschia fonticola & 76 & 46 & 670 & 232 & 1024 & 5.1 & 15.9 \\
\hline Staurosira construens f. venter & 72 & 43 & 645 & 270 & 1030 & 5.2 & 13.3 \\
\hline Fragilaria capucina v. vaucheria & 69 & 40 & 664 & 258 & 1031 & 5.2 & 63.4 \\
\hline Frustulia vulgaris & 64 & 34 & 713 & 227 & 1038 & 5.2 & 54.0 \\
\hline Navicula cincta & 59 & 38 & 655 & 289 & 1041 & 5.2 & 4.5 \\
\hline Gyrosigma acuminatum & 55 & 58 & 668 & 267 & 1048 & 5.2 & 5.1 \\
\hline Nitzschia frustulum & 59 & 44 & 717 & 233 & 1053 & 5.3 & 36.9 \\
\hline Gomphonema parvulum & 60 & 35 & 714 & 246 & 1055 & 5.3 & 63.0 \\
\hline Staurosirella pinnata & 65 & 39 & 708 & 256 & 1068 & 5.3 & 8.3 \\
\hline Staurosira construens & 65 & 47 & 706 & 252 & 1070 & 5.4 & 29.9 \\
\hline Entomoneis paludosa & 105 & 31 & 723 & 221 & 1080 & 5.4 & 2.5 \\
\hline Eunotia pectinalis v. undulata & 60 & 30 & 754 & 236 & 1080 & 5.4 & 28.0 \\
\hline Cymbella aspera & 61 & 44 & 755 & 225 & 1085 & 5.5 & 16.6 \\
\hline Cymbella tumida & 62 & 21 & 829 & 180 & 1092 & 5.5 & 7.6 \\
\hline Ctenophora pulchella & 27 & 44 & 744 & 277 & 1092 & 5.5 & 3.2 \\
\hline Gomphonema minutum & 76 & 37 & 730 & 259 & 1102 & 5.5 & 35.3 \\
\hline Stauroneis anceps & 103 & 29 & 730 & 248 & 1110 & 5.6 & 5.1 \\
\hline Planothidium lanceolatum & 62 & 43 & 763 & 264 & 1132 & 5.7 & 74.5 \\
\hline Surirella brebissonii & 54 & 41 & 898 & 190 & 1183 & 5.9 & 8.0 \\
\hline Meridion circulare & 66 & 43 & 838 & 239 & 1186 & 5.9 & 50.3 \\
\hline Cocconeis placentula f. lineata & 72 & 46 & 801 & 270 & 1189 & 6.0 & 70.3 \\
\hline Nitzschia vermicularis & 83 & 90 & 643 & 380 & 1196 & 6.0 & 5.2 \\
\hline Nitzschia dissipata & 76 & 46 & 817 & 263 & 1202 & 6.0 & 53.0 \\
\hline Luticola goeppertiana & 84 & 34 & 923 & 173 & 1214 & 6.1 & 5.1 \\
\hline Navicula rhynchocephala & 79 & 30 & 843 & 265 & 1217 & 6.1 & 29.3 \\
\hline Cymbopleura naviculiformis & 73 & 34 & 954 & 158 & 1219 & 6.1 & 7.6 \\
\hline Nitzschia linearis & 53 & 47 & 870 & 258 & 1228 & 6.2 & 46.9 \\
\hline Rhoicosphenia abbreviata & 61 & 44 & 862 & 286 & 1253 & 6.3 & 38.2 \\
\hline Ulnaria ulna & 80 & 49 & 852 & 286 & 1267 & 6.4 & 77.8 \\
\hline Nitzschia amphibia & 73 & 49 & 912 & 238 & 1272 & 6.4 & 6.4 \\
\hline Amphora ovalis & 46 & 61 & 913 & 273 & 1293 & 6.5 & 5.6 \\
\hline Cocconeis pediculus & 67 & 67 & 857 & 304 & 1295 & 6.5 & 8.9 \\
\hline Stauroneis phoenicenteron & 106 & 45 & 865 & 289 & 1305 & 6.5 & 8.2 \\
\hline Nitzschia palea & 70 & 42 & 937 & 258 & 1307 & 6.5 & 30.6 \\
\hline Navicula gregaria & 69 & 52 & 929 & 267 & 1317 & 6.6 & 36.0 \\
\hline Surirella brebissonii v. kuetzingii & 51 & 68 & 1032 & 259 & 1410 & 7.1 & 5.7 \\
\hline Cymatopleura solea & 55 & 58 & 989 & 316 & 1418 & 7.1 & 8.3 \\
\hline Nitzschia acicularis & 81 & 38 & 1052 & 289 & 1460 & 7.3 & 3.8 \\
\hline Nitzschia filiformis & 76 & 50 & 1084 & 272 & 1482 & 7.4 & 31.8 \\
\hline Surirella angustata & 61 & 53 & 1137 & 267 & 1518 & 7.6 & 16.7 \\
\hline Aulacoseira ambigua & 86 & 57 & 1110 & 268 & 1521 & 7.6 & 22.3 \\
\hline Hippodonta capitata & 86 & 57 & 1110 & 294 & 1547 & 7.7 & 9.5 \\
\hline Entomoneis alata & 74 & 34 & 1160 & 366 & 1634 & 8.2 & 2.5 \\
\hline Bacillaria paradoxa & 81 & 37 & 1202 & 332 & 1652 & 8.3 & 4.5 \\
\hline Surirella minuta & 53 & 51 & 1352 & 269 & 1725 & 8.6 & 5.6 \\
\hline Surirella ovalis & 72 & 61 & 1390 & 251 & 1774 & 8.9 & 3.2 \\
\hline Melosira varians & 93 & 71 & 1277 & 358 & 1799 & 9.0 & 42.0 \\
\hline Nitzschia sigmoidea & 102 & 127 & 1316 & 455 & 2000 & 10.0 & 5.7 \\
\hline
\end{tabular}

and their presence suggested elevated embeddedness and nutrients in stream channels throughout much of the study area. These species were common in the lowland agricultural region west of the Cascade Range. Van Dam et. al. (1994) and Potapova and Charles 
(2007) also found these species to be associated with eutrophic conditions. In addition, $26 \%$ of the taxa were considered motile in soft sediments (Kociolek and Spaulding 2003). In contrast, species with the highest relative abundance typically had the greatest tolerance to variation in the measured parameters, whereas more sensitive species had the lowest tolerance.

The diatom tolerance index (DTI) indicated that keeled and canalled-raphed diatoms were more common in habitats with high EMBI values or highly silted substrates. It is notable that over $50 \%$ of the species with high WADJUS had keeled or canalled raphe structures. In addition, these taxa were associated with high $\mathrm{TN}$ values. In contrast, araphid and monoraphid species with WADJUS values $\leq 4.0$ comprised $40 \%$ of taxa associated with substrates such as plants, sand, and rocks (Kingston 2004).

Blinn and Ruiter (2013) developed a caddisfly tolerance index (CTI) for caddisfly species collected throughout Washington in the same habitats at the same time as the diatoms. Tolerance values were comparable for the dominant components at both primary (diatom) and secondary (caddisfly) levels of the food chain. Diatom species with high DTI values occupied the same habitats as caddisfly species with high CTI values. For example, C. placentula v. lineata, M. varians, Navicula rhynchocephala, and P. lanceolatum, all with a DTI $\geq 1132$, made up $33 \%$ of the diatom assemblage in Johnson Creek, and Hydrotila xera $($ CTI $=1097)$ made up $89 \%$ of the caddisfly assemblage. In contrast, $A$. alpigena, D. balfourniana, and T. glans in Upper Galena Cr. had low DTI values ranging from 162 to 457 (Table 5) and were associated with caddisflies (Ecclisocosmoecus scylla, Hesperophylax alaskensis, Ecclisomyia conspersa, Ecclisomyia maculosa) with CTI values $\leq 133$.

Table 6 provides a monitoring program utilizing diatom assemblages from 165 aquatic systems in the state of Washington. Diatom assemblages are provided for the 3 condition levels of stream environments (good, fair, and poor condition). Potapova and Charles (2007) found that diatom indices developed in certain parts of the USA are not as effective when used in other regions of the same continent. Therefore, DTI values for individual species derived from streams, rivers, and lakes in
Washington provide a more accurate index for monitoring the status of various watersheds in the state.

Didymosphenia geminata was first reported in North America on Vancouver Island, British Columbia, in the late 1800s (Spaulding and Elwell 2007). More recently, Bahls (20042006) reported low numbers of $D$. geminata in 11 stream and river periphyton samples collected in Washington. The most suitable habitats for D. geminata were predicted to occur in the western United States, in relatively cool sites, and at high elevations with a high baseflow index (Kumar et al. 2009).

Sutherland et al. (2007) reported that substrates colonized by $D$. geminata in the laboratory died or disappeared when positioned in spring-fed creeks in New Zealand, while those placed in rivers showed growth. In addition, they found water in spring-fed creeks had higher nitrate concentrations and specific conductivity than river waters.

Although nitrates were not measured, similar patterns were found for $\mathrm{TN}$ and specific conductivity in Washington streams and rivers. The average $\mathrm{TN}$ in streams was $134 \mu \mathrm{g}$ - $\mathrm{L}^{-1}$ (SE 35) compared to $93 \mu \mathrm{g} \cdot \mathrm{L}^{-1}$ (SE 7.9) in rivers. Furthermore, the average relative frequency of D. geminata was $2.2 \%$ (SE 0.6 ) in streams compared to $4.7 \%$ (SE 2.1) in rivers. This further suggests that elevated nitrogen has a negative influence on the growth of this invasive alga. Also, higher TN values in streams and rivers on the west side of the Cascades compared to those on the east side may explain the higher percentage of sites with $D$. geminata on the east side of the Cascades.

Eighty-seven percent of the river sites sampled contained D. geminata compared to $33 \%$ of the stream sites sampled. This likely resulted from higher TN concentrations in streams compared to rivers. Many of the small streams examined were spring-fed with high TN concentrations, while larger rivers had a lower average $\mathrm{TN}$ concentration. River sites without $D$. geminata had an average TN concentration of $531 \mu \mathrm{g} \cdot \mathrm{L}^{-1}$ (SE 157). Twentynine river systems contained $D$. geminata, including all forks of the Nooksack River system. The transport of $D$. geminata by fishermen in the Nooksak River drainage may have been responsible for the high occurrence of this invasive species. 


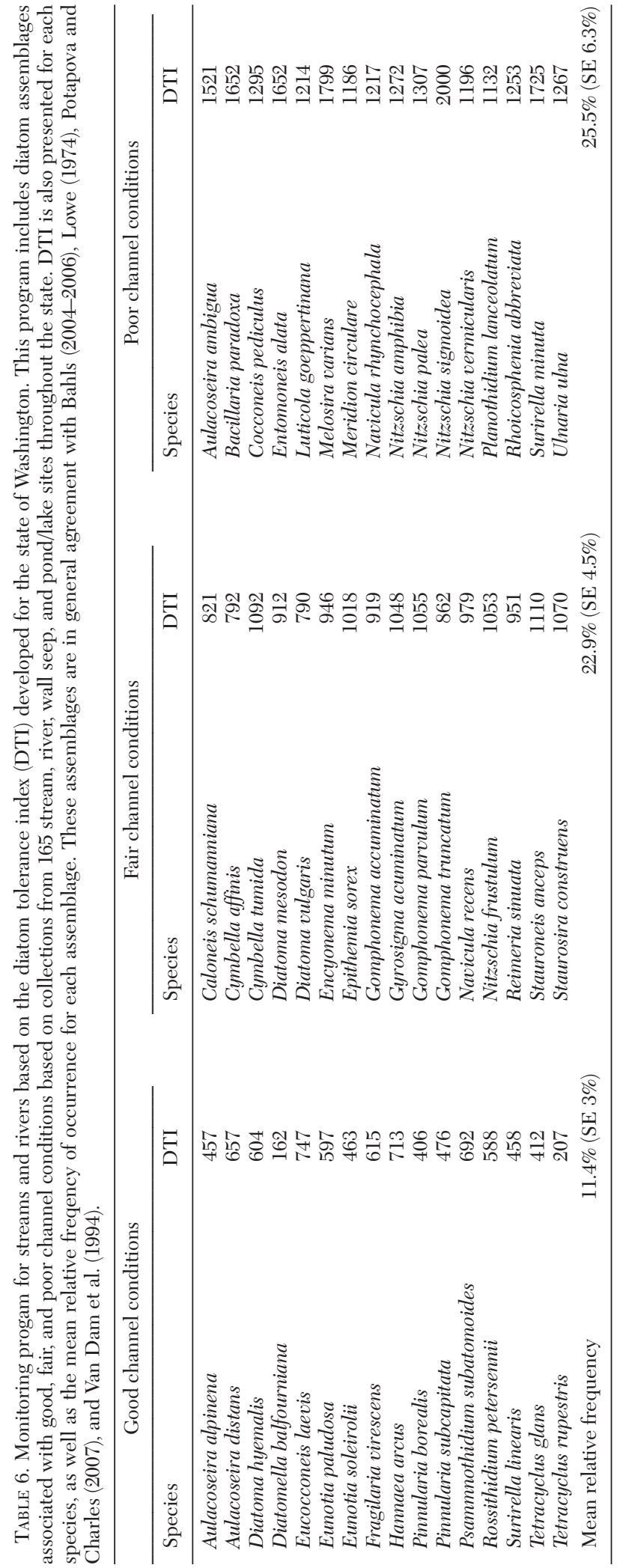


The absence of $D$. geminata in the Elwa River is likely due to the abrasive high suspended solids in this river. Similar patterns were observed in Glacier and Barr creeks, both with high suspended solid loads (Appendix 1). Although the Elwa River on the Olympic Peninsula had relatively low TN concentration, the abrasive nature of a high suspended sediment load may have restricted the occurrence of this invasive alga in this system (Appendix 1). However, Reid and Torres (2014) recently reported increases in soluble reactive phosphorus uptake within $D$. geminata biomass associated with fine sediments because of altered redox conditions within the algal biomass. Didymosphenia geminata ranked in the top $25 \%$ of the diatom tolerance index with a value of 707 (Table 5). The negative correlation to altitude may have resulted from limited dispersal vectors to isolated, highaltitude sites.

Studies of streams in New Zealand and North America have demonstrated that $D$. geminata populations decrease with high numbers of Ephemeroptera, Plecoptera, and Trichoptera insect trophic groups, and increase with dipterans, crustaceans, and oligochaetes (Gillis and Chalifour 2010, James et al. 2010, Larned and Kilroy 2014). This has a major effect on the aquatic food web in streams and rivers.

Future studies are needed in the Columbia Unglaciated freshwater ecoregion that runs along the southern border of Washington and into Oregon and Idaho in the Blue Mountains of the Umatilla National Forest (Abell et al. 2000). This region escaped glaciation during the Pleistocene and may yield endemic diatoms not included in this study or in Bahls's (2009) checklist of species in northwestern USA. This may be especially true for seeps and springs in the region.

\section{ACKNOWLEDGMENTS}

I thank Ashley Rawhouser and Dr. Leo Bodensteiner for collections in the North Cascades National Park. I also thank Joan Vandersypen and Dr. Robin Matthews at the Institute for Watershed Studies at Western Washington University for nutrient analyses. Dr. Matthews also provided multilevel hierarchical clustering models and Kendall's $\tau$ rank-based correlations between species richness and abiotic factors.

\section{Literature Cited}

Abell, R.A., D.M. Olson, E. Dinerstein, P.T. Hurley, J.T. Diggs, W. Eichbaum, S. Walter, W. Wettengel, T. Allnutt, C.L. Louck, and P. Hedao. 2000. Freshwater ecoregions of North America: a conservation assessment. Inland Press, Washington, DC. 319 pp.

[APHa] American Public Health Association. 2005. Standard methods for the examination of water and wastewater. 21st edition. American Public Health Association, American Water Works Association, and Water Environment Federation, Washington, DC.

BAHLS, L.L. 2004-2006. Northwest diatoms: a photographic catalogue of species in the Montana Diatom Collection, with ecological optima, associates, and distribution records for nine northwestern United States. 3 volumes. Hannaea, Helena, MT.

2009. A checklist of diatoms from inland waters of the northwestern United States. Proceedings of the Academy of Natural Sciences of Philadelphia 158: $1-35$.

Barbour, M.T., J.B. Stribling, And J.R. KarR. 1995. Multimetric approach for establishing biocriteria and measuring biological condition. Pages 63-77 in W.S. Davis and T.P. Simon, editors, Biological assessment and criteria: tools for water resource planning and decision making. Lewis Publishers, Boca Raton, FL.

Ben-Hur, A., AND I. GuYon. 2003. Detecting stable clusters, using principal components analysis. Pages 159-182 in M.J. Brounsterin and A. Kohodursdy, editors, Methods in molecular biology. Humana Press, New York, NY.

Bennett, W.A.G. 1962. Saline lake deposits in Washington. Bulletin No. 49, Division of Mines and Geology. $129 \mathrm{pp}$.

BLInN, D.W. 1993. Diatom community structure along physicochemical gradients in saline lakes. Ecology 74:1246-1263.

BLInN, D.W., AND D.E. Ruiter. 2006. Tolerance values of stream caddisflies (Trichoptera) in the Lower Colorado River Basin, USA. Southwestern Naturalist 51: 326-337.

2013. Tolerance values and effects of selected enviromental determinants of caddisfly (Trichoptera) distribution in northwest and north central Washington, USA. Western North American Naturalist 73: 270-294.

Cooke, S.E., and E.E. Prepas. 1998. Stream phosphorus and nitrogen export from agricultural and forested watersheds on the Boreal Plain. Canadian Journal of Fisheries and Aquatic Sciences 10:2292-2299.

Crawley, M.J. 2007. The R book. Wiley Online Library. http://dx.doi.org/10.1002/9780470515075

Enache, M.D., M. Potapova, R. Sheibley, and P.W. Moran. 2013. Three new Psammothidium species from lakes of Olympic and Cascade Mountains in Washington State, USA. Phytotaxa 127:49-57.

ENGER, E., AND B. SMITH. 2009. Environmental science: a study of interrelationships. McGraw Hill, New York, NY. 512 pp.

Fore, L.S., AND C. GRAFE. 2002. Using diatoms to assess the biological condition of large rivers in Idaho (U.S.A.). Freshwater Biology 47:2015-2037.

Gillis, C., AND M. Chalifour. 2010. Changes in the macrobenthic community structure following the introduction of the invasive algae Didymosphenia geminata 
in the Matapedia River (Quebec, Canada). Hydrobiologia 647:63.

Hawkins, C.P., and R.N. NorRis. 2000. Performance of different landscape classifications for aquatic bioassessments: introduction to the series. Journal of the North American Benthological Society 19:367-369.

Hollingshead, K.D. 2012. Diatoms in Castor Lake (north-central Washington, USA): proxies of climate and hydrologic variation. Master's thesis, University of Western Ontario, London, Canada. 119 pp.

James, D.A., S.H. Ranney, S.R. Chipps, and B.D. SPINDLER. 2010. Invertebrate composition and abundance associated with Didymosophenia geminata in a montane stream. Journal of Freshwater Ecology 25: 235-241.

JONGMAN, R.H.G., C.J.F. TER BRAAK, AND O.F.R. VAN TONGEREN, EDITORS. 1995. Data analysis in community and landscape ecology. Cambridge University Press. $212 \mathrm{pp}$.

Kauffman, J.B., and W.C. Krueger. 1984. Livestock impacts on riparian ecosystems and streamside management implications: a review. Journal of Range Management 37:430-438.

Kingston, J.C. 2004. Araphid and monoraphid diatoms. Pages 595-636 in J.D. Wehr and R.C. Sheath, editors, Freshwater algae of North America: ecology and classification. Elsevier Science (USA).

Kociolek, J.P. 2006. Some thoughts on the development of a diatom flora for freshwater ecosystems in the continental United States and a listing of recent taxa described from U.S. freshwaters. Proceedings of the California Academy of Sciences 57(21):561-586.

Kociolek, J.P., And S.A. Spaulding. 2003. Symmetrical naviculoid diatoms. Pages 637-653 in J.D. Wehr and R.C. Sheath, editors, Freshwater algae of North America: ecology and classification.

Krammer, K., and H. Lange-Bertalot. 1986. Bacillariophyceae. Teil 1. Naviculaceae. In: H. Ettl, J. Gerloff, H. Heynig, and D. Mollenhauer, editors, Süsswasserflora von Mitteleuropa. Band 2/1. Gustav Fisher Verlag, Stuttgart, Germany. 876 pp.

1988. Bacillariophyceae. Teil 2. Bacillariaceae, Epithemiaceae, Surirellaceae. In: H. Ettl, J. Gerloff, H. Heynig, and D. Mollenhauer, editors, Süsswasserflora von Mitteleuropa. Band 2/2. Gustav Fisher, Stuttgart, Germany. 596 pp.

1991a. Bacillariophyceae. Teil 3. Centrales, Fragilariaceae, Eunotiaceae. In: H. Ettl, J. Gerloff, H. Heynig, and D. Mollenhauer, editors, Süsswasserflora von Mitteleuropa, Band 2/3. Gustav Fischer Verlag, Stuttgart, Germany. 576 pp.

. 1991b. Bacillariophyceae. Teil 4. Achnanthaceae. Kritische Ergänzungen zu Navicula and Gomphonema. In: H. Ettl, J. Gerloff, H. Heynig, and D. Mollenhauer, editors, Süsswasserflora von Mitteleuropa. Band 2/4. Gustav Fischer Verlag, Stuttgart, Jena, Germany. 437 pp.

2000. Bacillariophyceae. Part 5. English and French translation of the keys. Süsswasserflora von Mitteleuropa. Spektrum Akademischer Verlag, Heidelberg/Berlin, Germany. 311 pp.

Kumar, S., S.A. Spaulding, T.J. Stohlgren, K.A. Hermann, T.S. Schmidt, AND L.L. Bahls. 2009. Potential habitat distribution for the freshwater diatom Didymosphenia geminata in the continental US. Frontiers in Ecology and the Environment 7: $415-420$
Larned, S.T., And C. Kilroy. 2014. Effects of Didymosphenia geminata removal on river macroinvertebrate communities. Journal of Freshwater Ecology 29:345-362.

LAWS, E.A. 2000. Aquatic pollution: an introductory text. 3rd edition. John Wiley \& Sons, New York, NY. 672 pp.

LEE, C.J., AND A.C. Ziegler. 2010. Effects of urbanization, construction activity, management practices and impoundments on suspended-sediment transport in Johnson County, northeast Kansas, February 2006 through November 2008. U.S. Geological Survey Scientific Investigations Report 2010-5128. 54 pp.

LowE, R.L. 1974. Environmental requirements and pollution tolerance of freshwater diatoms. EPA-670/4-74005. Cincinnati, OH.

MacDonald, L.H., A.W. Smart, and R.C. Wissmar. 1991. Monitoring guidelines to evaluate effects of forestry activities on streams in the Pacific Northwest and Alaska. EPA 910/9-91-001, U.S. Environmental Protection Agency, Seattle, WA. 166 pp.

Platts, W.S., W.F. Megahan, and G.W. Minshall. 1983. Methods for evaluating stream, riparian, and biotic conditions. General Technical Report INT-138, USDA Forest Service, Odgen, UT.

Potapova, M., AND D.F. Charles. 2007. Diatom metrics for monitoring eutrophication in rivers of the United States. Ecological Indicators 7:48-70.

R Development Core Team. 2011. R: a language and environment for statistical computing. R Foundation for Statistical Computing, Vienna, Austria. ISBN 3-9090051-07-0. http://www.R-project.org

ReID, B., AND R. TORREs. 2014. Didymosphenia geminata invasion in South America: ecosystem impacts and potential biogeochemical state change in Patagonian rivers. Acta Oecologica 54:101-109.

Rosenfeld, C. 1985. Landforms and geology. Page 40 in A.J. Kimerling and P.L. Jackson, editors, Atlas of the Pacific Northwest.

Sheibley, R.W., M. Enache, P.W. Swarzenski, P.W. Moran, and J.R. Formeman. 2014. Nitrogen deposition effects on diatom communities in lakes from three National Parks in Washington State. Water, Air, and Soil Pollution 225:1-23.

Sovereign, H.E. 1963. New and rare diatoms from Oregon and Washington. Proceedings of the California Academy of Sciences 31:349-368.

SPAulding, S.A., AND L. ElwEll. 2007. Increase in nuisance blooms and geographic expansion of the freshwater diatom Didymosphenia geminata. U.S. Geological Survey Open-File Report 2007-1425, U.S. Department of the Interior and U.S. Geological Survey. $38 \mathrm{pp}$.

Stevenson, R.J. 2014. Ecological assessments with algae: a review and synthesis. Journal of Phycology 50: $437-461$.

Stevenson, R.J., Y. Pan, K.M. Manoylov, C.A. Parker, D.P. Larsen, and A.T. Herlihy. 2008. Development of diatom indicators of ecological conditions for streams of the western US. Journal of the North American Benthological Society 27:1000-1016.

Stockner, J.G., AND W.W. Benson. 1967. The succession of diatom assemblages in the recent sediments of Lake Washington. Limnology and Oceanography 12: 513-532.

Sutherland, S., M. Rodway, C. Kilroy, B. Jarvie, and G. Hughes. 2007. The survival of Didymosphenia 
geminata in the rivers and associated spring-fed tributaries in the South Island of New Zealand. MAF Biosecurity New Zealand. 38 pp.

Tynni, R. 1986. Observations of diatom on the coast of the state of Washington. Geological Survey of Finland. Report of Investigation 75. $25 \mathrm{pp}+32$ plates.

United States Census Bureau. 2013. State and country quick facts. U.S. Department of Commerce; [accessed 6 January 2013]. http://quickfacts.census.gov.

Van Dam, H., A. Mertens, and J. Sinkeldam. 1994. A coded checklist and ecological indicator values of freshwater diatoms from the Netherlands. Netherlands Journal of Aquatic Ecology 28:117-133.

Wallace, A.R., D.G. Frank, and A. Founie. 2006. Freshwater diatomite deposits in the western United States. Fact Sheet 2006-3044, U.S. Geological Survey.

Received 12 August 2014 Accepted 25 December 2014

Appendix 1 on page 30

Appendix 2 on page 36 
APPENDIX 1. Site, location, altitude (ALTI), maximum water temperature (MTEM), total phosphorus (TP), total nitrogen diatom richness (RICH), and $\mathrm{H}^{\prime}$ for 165 aquatic habitats in northwestern Washington, USA, including North Cascades listed in order of increasing altitude. Letters for 6 clusters in Fig. 1 are provided. Counties: $\mathrm{CH}=$ Chelan, CLA = Whatcom. NA $=$ not available; NCNP $=$ North Cascades National Park. Lakes and ponds are in boldface type. Woolley, WA. An asterisk (*) indicates that Didymosphenia geminata was collected. (Data taken in part from Blinn and

\begin{tabular}{|c|c|c|c|c|}
\hline $\begin{array}{c}\text { Cluster } \\
\text { letter }\end{array}$ & SITE & LOCATION & $\begin{array}{c}\text { ALTI } \\
(\mathrm{m})\end{array}$ & $\begin{array}{c}\text { MTEM } \\
\left({ }^{\circ} \mathrm{C}\right)\end{array}$ \\
\hline$* \mathrm{~A}$ & Nooksack River on Slater Rd. (WH) & N48.818168 W122.5803 & 3 & 20 \\
\hline A & California Cr.; Knickerville Rd. (WH) & N48.947139 W122.7044 & 4 & 27 \\
\hline $\mathrm{C}^{1}$ & Squalicum Cr.; Bellingham $(\mathrm{WH})$ & N48.765213 W122.5022 & 5 & 19 \\
\hline A & California Cr.; Valley View Rd. (WH) & N48.920695 W122.6601 & 7 & 19 \\
\hline A & Sammamish River (KIN) & $\mathrm{N} 47.66036 \mathrm{~W} 122.12372$ & 7 & 17 \\
\hline A & Terrell Cr. on Jackson Rd. (WH) & $\mathrm{N} 48.89690 \mathrm{~W} 122.74884$ & 10 & 19 \\
\hline A & Johnson Cr. in Sumas, WA (WH) & $\mathrm{N} 48.99828 \mathrm{~W} 122.26665$ & 13 & 20 \\
\hline $\mathrm{C}^{1}$ & Oyster Cr.; Chuckanut Drive (SK) & $\mathrm{N} 48.61770 \mathrm{~W} 122.43954$ & 13 & 17 \\
\hline $\mathrm{D}$ & Hoko River on Hoko Ozette Rd. (CLA) & $\mathrm{N} 48.25867 \mathrm{~W} 124 / 35221$ & 15 & 15 \\
\hline $\mathrm{C}^{1}$ & Chuckanut Cr.; Fairhaven (WH) & N48.71569 W122.49484 & 15 & 19 \\
\hline A & Tenmile Cr. on Tenmile Rd. (WH) & N48.86994 W122.46700 & 22 & 19 \\
\hline $\mathrm{A}$ & Fourmile Cr. on Tenmile Rd. $(\mathrm{WH})$ & $\mathrm{N} 48.86980 \mathrm{~W} 122.48189$ & 22 & 21 \\
\hline$* \mathrm{C}^{1}$ & Green Cr. on Hwy. 112 (CLA) & $\mathrm{N} 48.17839 \mathrm{~W} 124.20638$ & 23 & 16 \\
\hline $\mathrm{C}^{1}$ & Fever Cr.; Bellingham (WH) & N48.77181 W122.44167 & 24 & 18 \\
\hline$* \mathrm{~B}$ & Dungeness River on Ward Rd. (CLA) & $\mathrm{N} 48.11823 \mathrm{~W} 123.14843$ & 24 & 14 \\
\hline A & Scudder Pond, Bellingham (WH) & N48.76162 W122.42091 & 25 & 25 \\
\hline $\mathrm{A}$ & Elwa River on Elwa Rd. (CLA) & $\mathrm{N} 48.11376 \mathrm{~W} 123.55392$ & 25 & 16 \\
\hline $\mathrm{C}^{1}$ & Breckenridge Cr. Goodwin Rd. (WH) & $\mathrm{N} 48.88900 \mathrm{~W} 122.28790$ & 25 & 19 \\
\hline$* \mathrm{C}^{1}$ & White Cr. (Mi. 60.6) Hwy. 530 (SK) & N48.39765 W121.55106 & 99 & 19 \\
\hline $\mathrm{C}^{1}$ & Whatcom Cr.; Bellingham (WH) & N48.75329 W122.43503 & 25 & 22 \\
\hline$* A$ & Nooksack River at Everson (WH) & N48.91771 W122.34920 & 26 & 18 \\
\hline $\mathrm{B}$ & Snoqualamie River in Fall City (KIN) & N47.56819 W121.88284 & 26 & 15 \\
\hline $\mathrm{C}^{1}$ & Unknown stream to Dakota Cr. (WH) & N48.96522 W122.66006 & 27 & 19 \\
\hline A & Fish Trap Cr. (Hwy. 546) (WH) & $\mathrm{N} 48.96427 \mathrm{~W} 122.43164$ & 33 & 20 \\
\hline $\mathrm{A}$ & Sumas River on Lindsay Rd. (WH) & N48.94922 W122.30856 & 33 & 20 \\
\hline$* \mathrm{~A}$ & Nooksack River at Cedarville (WH) & $\mathrm{N} 48.84179 \mathrm{~W} 122.29380$ & 33 & 22 \\
\hline$* \mathrm{~B}$ & Stilliquamish River on Strotz Rd. (SN) & N48.19859 W122.20468 & 34 & 16 \\
\hline $\mathrm{C}^{1}$ & Bear Cr.; Cain Lk. Rd. (SK) & N48.62792 W122.36263 & 40 & 18 \\
\hline$* \mathrm{~B}$ & Bogachiel River on Hwy. 101 (CLA) & N47.89416 W124.35709 & 44 & 17 \\
\hline $\mathrm{B}$ & Olney Cr. 9 Mi. 26.5 on Hwy. 2 (SN) & N47.87764 W121.71800 & 44 & 18 \\
\hline$* \mathrm{~A}$ & Baker River in Concrete (SK) & N48.53707 W121.74216 & 48 & 19 \\
\hline $\mathrm{D}$ & Anderson Cr. on Oil City Rd. (JEF) & N47.77206 W124.32293 & 48 & 14 \\
\hline $\mathrm{B}$ & Swift Cr. bridge on Goodwin Rd. (WH) & $\mathrm{N} 48.90595 \mathrm{~W} 122.28746$ & 50 & 21 \\
\hline $\mathrm{D}$ & Lost Cr. on Hwy. 101 (JEF) & $\mathrm{N} 47.78170 \mathrm{~W} 124.27018$ & 52 & 15 \\
\hline$* \mathbf{C}^{2}$ & Grandy Cr. (Mi. 82.7) Hwy. 20 (SK) & $\mathrm{N} 48.53285 \mathrm{~W} 121.88413$ & 53 & 25 \\
\hline$* \mathrm{D}$ & Smith Cr. (Mi. 11.4) Hwy. 542 (WH) & $\mathrm{N} 48.84145 \mathrm{~W} 122.26037$ & 54 & 16 \\
\hline$* \mathrm{C}^{1}$ & Jackman Cr. (Mi. 91) Hwy. 20 (SK) & N48.53079 W121.71985 & 55 & 21 \\
\hline A & Wiser Lake near Lynden (WH) & $\mathrm{N} 48.90516 \mathrm{~W} 122.48491$ & 57 & 27 \\
\hline$* \mathrm{~B}$ & Calawah River on Hwy. 101 (CLA) & N47.95981 W124.39283 & 60 & 17 \\
\hline $\mathbf{A}$ & Lake Terrell (WH) & N48.86054 W122.68965 & 65 & 28 \\
\hline$* \mathrm{~B}$ & Nooksack River (Hwy. 9 bridge) $(\mathrm{WH})$ & N48.86054 W122.89650 & 69 & 16 \\
\hline$* \mathrm{D}$ & Bacon Cr. (Mi. 110.8) Hwy. 20 (SK) & N48.58796 W121.39524 & 70 & 16 \\
\hline A & Lake Padden, Bellingham (WH) & N48.70138 W122.44709 & 74 & 20 \\
\hline $\mathrm{C}^{1}$ & Padden Cr.; Padden Cr. Park (WH) & $\mathrm{N} 48.70277 \mathrm{~W} 122.24465$ & 75 & 18 \\
\hline A & Sammish Lake, Bellingham WA (WH) & N48.67045 W122.38134 & 75 & 21 \\
\hline$* \mathrm{~B}$ & Skagit River at Rockport (SK) & N48.48464 W121.59299 & 76 & 16 \\
\hline $\mathrm{D}$ & Stream/waterfall at Mi. 245 on I-5 (WH) & N48.67373 W122.38669 & 80 & 13 \\
\hline $\mathrm{C}^{1}$ & Samish River (old Hwy. 99) (SK) & $\mathrm{N} 48.52577 \mathrm{~W} 122.34008$ & 82 & 16 \\
\hline$* \mathrm{~B}$ & N. F. Stillaquamish Hwy. 530) (SN) & $\mathrm{N} 48.27748 \mathrm{~W} 121.80850$ & 83 & 16 \\
\hline $\mathrm{C}^{1}$ & Friday Cr.; Friday Cr. Rd. (SK) & $\mathrm{N} 48.57403 \mathrm{~W} 122.33828$ & 90 & 19 \\
\hline $\mathbf{A}$ & Lake Whatcom; Agate Bay (WH) & N48.75664 W122.35585 & 93 & 19 \\
\hline$* \mathrm{~B}$ & Sauk River (Mi. 61.6) Hwy. 530 (SK) & $\mathrm{N} 48.40871 \mathrm{~W} 121.55528$ & 93 & 19 \\
\hline $\mathrm{D}$ & Unknown stream by Whatcom Lk. (WH) & $\mathrm{N} 48.70716 \mathrm{~W} 122.29792$ & 96 & 15 \\
\hline$* \mathrm{~B}$ & Skagit River at Marblemount WA (SK) & $\mathrm{N} 48.52704 \mathrm{~W} 121.42845$ & 96 & 14 \\
\hline $\mathrm{D}$ & Carpenter Cr.; Bellingham (WH) & $\mathrm{N} 48.75664 \mathrm{~W} 122.35486$ & 96 & 15 \\
\hline $\mathrm{D}$ & Wall Seep at Mi. $71.3 \mathrm{Hwy} 9(\mathrm{WH})$ & N48.69127 W122.19295 & 98 & 16 \\
\hline$* \mathrm{~B}$ & N. Fork Nooksack on Mosquito Rd. (WH) & N48.78476 W122.11269 & 98 & 15 \\
\hline $\mathrm{C}^{1}$ & Anderson Cr. bridge on Hwy. 542 (WH) & N48.79027 W122.42083 & 103 & 18 \\
\hline
\end{tabular}


(TN), specific conductance (SPCO), canopy cover (CAN), embeddedness (EMBE), suspended sediment (SUSE), National Park, Olympic Peninsula, and Mt. Baker-Snoqualmie, Okanogan, and Wenatchee National Forests. Sites are Clallam, JEF $=$ Jefferson, KIN $=$ King, KIT $=$ Kittitas, $\mathrm{OK}=$ Okanogan, $\mathrm{SK}=$ Skagit, $\mathrm{SN}=$ Snohomish, WH $=$ Information and collections by National Park Service and North Cascades National Park Service Complex; Sedro Ruiter 2013).

\begin{tabular}{|c|c|c|c|c|c|c|c|}
\hline $\begin{array}{c}\mathrm{TP} \\
\left(\mu \mathrm{g} \cdot \mathrm{L}^{-1}\right)\end{array}$ & $\begin{array}{c}\mathrm{TN} \\
\left(\mu \mathrm{g} \cdot \mathrm{L}^{-1}\right)\end{array}$ & $\begin{array}{c}\mathrm{SPCO} \\
\left(\mathrm{mS} \cdot \mathrm{cm}^{-1}\right)\end{array}$ & $\begin{array}{c}\text { CAN } \\
(\%)\end{array}$ & $\begin{array}{c}\text { EMBE } \\
(\%)\end{array}$ & $\begin{array}{c}\text { SUSE } \\
\left(\mathrm{mg} \cdot \mathrm{L}^{-1}\right)\end{array}$ & RICH & $\mathrm{H}^{\prime}$ \\
\hline 58 & 190 & 0.110 & 5 & 95 & 16 & 53 & 4.68 \\
\hline 30 & 2359 & 26.20 & 5 & 95 & 4 & 46 & 5.04 \\
\hline 25 & 578 & 0.247 & 30 & 55 & 5 & 53 & 3.74 \\
\hline 181 & 3238 & 0.381 & 95 & 95 & 2 & 38 & 4.54 \\
\hline 17 & 437 & 0.105 & 10 & 90 & 2 & 69 & 4.76 \\
\hline 209 & 1209 & 0.490 & 95 & 95 & 1 & 45 & 4.92 \\
\hline 84 & 5615 & 0.264 & 85 & 85 & 5 & 53 & 4.25 \\
\hline 4 & 1420 & 1.187 & 85 & 10 & 2 & 40 & 4.02 \\
\hline 15 & 225 & 0.085 & 85 & 10 & 1 & 28 & 2.95 \\
\hline 11 & 951 & 0.243 & 90 & 15 & 2 & 29 & 3.49 \\
\hline 52 & 817 & 0.340 & 5 & 95 & 3 & 40 & 4.58 \\
\hline 85 & 3157 & 0.386 & 5 & 95 & 5 & 37 & 4.37 \\
\hline 15 & 329 & 0.087 & 75 & 35 & 1 & 35 & 3.94 \\
\hline 19 & 527 & 0.262 & 60 & 40 & 1 & 36 & 3.48 \\
\hline 6 & 94 & 0.102 & 25 & 20 & 1 & 45 & 4.45 \\
\hline 99 & 787 & 0.182 & 0 & 95 & 1 & 41 & 4.20 \\
\hline 112 & 121 & 0.084 & 20 & 75 & 279 & 14 & 2.21 \\
\hline 19 & 401 & 0.244 & 90 & 15 & 3 & 42 & 3.85 \\
\hline 5 & 66 & 0.060 & 80 & 15 & 1 & 57 & 3.56 \\
\hline 8 & 440 & 0.226 & 20 & 20 & 4 & 57 & 3.56 \\
\hline 64 & 138 & 0.123 & 5 & 90 & 14 & 25 & 4.06 \\
\hline 23 & 432 & 0.052 & 5 & 85 & 3 & 24 & 3.47 \\
\hline 30 & 1021 & 0.180 & 85 & 20 & 2 & 29 & 2.74 \\
\hline 24 & 3429 & 0.303 & 45 & 85 & 5 & 39 & 3.32 \\
\hline 54 & 974 & 0.360 & 5 & 95 & 12 & 31 & 3.40 \\
\hline 20 & 105 & 0.080 & 5 & 80 & 156 & 38 & 3.33 \\
\hline 6 & 188 & 0.045 & 5 & 25 & 10 & 24 & 3.48 \\
\hline 4 & 609 & 0.102 & 80 & 25 & 2 & 33 & 3.19 \\
\hline 4 & 108 & 0.091 & 20 & 25 & 2 & 34 & 3.44 \\
\hline 26 & 221 & 0.038 & 10 & 45 & 35 & 42 & 4.27 \\
\hline 25 & 110 & 0.045 & 5 & 85 & 15 & 55 & 3.42 \\
\hline 14 & 235 & 0.068 & 90 & 15 & 1 & 28 & 3.51 \\
\hline 10 & 390 & 0.240 & 5 & 95 & 4 & 14 & 1.78 \\
\hline 17 & 88 & 0.093 & 95 & 20 & 1 & 14 & 0.93 \\
\hline 11 & 217 & 0.200 & 70 & 45 & 5 & 27 & 3.40 \\
\hline 7 & 275 & 0.099 & 85 & 35 & 1 & 17 & 1.72 \\
\hline 5 & 158 & 0.090 & 60 & 40 & 5 & 23 & 2.91 \\
\hline 86 & 1633 & 0.341 & 0 & 95 & 1 & 33 & 3.38 \\
\hline 8 & 278 & 0.093 & 20 & 30 & 2 & 33 & 2.71 \\
\hline 36 & 1149 & 0.098 & 0 & 99 & 2 & 44 & 4.40 \\
\hline 20 & 105 & 0.080 & 5 & 95 & 15 & 30 & 2.96 \\
\hline 4 & 68 & 0.040 & 50 & 20 & 1 & 29 & 3.45 \\
\hline 11 & 471 & 0.055 & 5 & 99 & 1 & 34 & 4.12 \\
\hline 10 & 638 & 0.183 & 95 & 10 & 1 & 42 & 4.63 \\
\hline 19 & 370 & 0.068 & 10 & 40 & 2 & 24 & 3.53 \\
\hline 16 & 35 & 0.088 & 50 & 10 & 10 & 10 & 3.77 \\
\hline 7 & 436 & 0.061 & 90 & 30 & 1 & 25 & 2.65 \\
\hline 9 & 757 & 0.128 & 60 & 40 & 4 & 37 & 3.77 \\
\hline 4 & 123 & 0.068 & 5 & 15 & 5 & 24 & 3.48 \\
\hline 8 & 572 & 0.135 & 80 & 15 & 2 & 64 & 5.06 \\
\hline 4 & 455 & 0.063 & 5 & 80 & 5 & 28 & 3.33 \\
\hline 28 & 31 & 0.050 & 5 & 20 & 150 & 34 & 3.17 \\
\hline 4 & 830 & 0.099 & 85 & 80 & 1 & 18 & 2.48 \\
\hline 7 & 71 & 0.040 & 10 & 90 & 5 & 46 & 4.05 \\
\hline 22 & 660 & 0.119 & 95 & 25 & 1 & 27 & 2.72 \\
\hline 31 & 363 & 0.085 & 75 & 20 & 1 & 25 & 2.95 \\
\hline 7 & 64 & 0.095 & 10 & 65 & 14 & 29 & 3.77 \\
\hline 18 & 400 & 0.126 & 85 & 20 & 1 & 38 & 3.89 \\
\hline
\end{tabular}


APPEndix 1. Continued.

\begin{tabular}{|c|c|c|c|c|}
\hline $\begin{array}{c}\text { Cluster } \\
\text { letter }\end{array}$ & SITE & LOCATION & $\begin{array}{l}\text { ALTI } \\
(\mathrm{m})\end{array}$ & $\begin{array}{c}\text { MTEM } \\
\left({ }^{\circ} \mathrm{C}\right)\end{array}$ \\
\hline$* \mathrm{C}^{2}$ & Canyon Cr. on Mosquito Lk. Rd. (WH) & N48.83365 W122.13649 & 105 & 17 \\
\hline $\mathrm{C}^{2}$ & Bell Cr. (Mi. 17.4) Hwy. $542(\mathrm{WH})$ & N48.84871 W122.16121 & 107 & 17 \\
\hline$* \mathrm{D}$ & S. Fork Nooksack on Saxon Rd. (WH) & N48.67807 W122.16582 & 108 & 16 \\
\hline $\mathrm{C}^{1}$ & Olsen Cr.; N. Shore Dr. Bellingham (WH) & N48.89768 W122.14376 & 114 & 20 \\
\hline $\mathrm{D}$ & Kendell Cr. Nooksack Hatchery (WH) & N48.89768 W122.14376 & 124 & 16 \\
\hline$* \mathrm{~B}$ & Hoh River at Hoh Ox Box camp (JEF) & N47.81239 W124.25117 & 125 & 16 \\
\hline$* \mathrm{C}^{2}$ & Rocky Cr. (Mi. 102.6) Hwy. 20 (SK) & N48.52644 W121.45381 & 133 & 18 \\
\hline$* \mathrm{~B}$ & Squire Cr. at Squire Cr. campground $(\mathrm{SN})$ & N48.27023 W121.67094 & 134 & 16 \\
\hline$* \mathrm{D}$ & Proctor Cr. (Mi. 31.2) Hwy. 2 (SN) & N47.83384 W121.64453 & 134 & 17 \\
\hline $\mathrm{C}^{1}$ & Beaver Cr. on Hwy. 113 (CLA) & N48.11969 W124.21705 & 135 & 17 \\
\hline $\mathbf{A}$ & Mirror Lake (WH) & N48.66279 W122.21809 & 135 & 22 \\
\hline $\mathrm{D}$ & Fir Cr.; Sudden Valley $(\mathrm{WH})$ & N48.67346 W122.26760 & 138 & 16 \\
\hline $\mathrm{D}$ & Brannian Cr.; Sudden Valley $(\mathrm{WH})$ & N48.66903 W122.28041 & 139 & 16 \\
\hline $\mathrm{D}$ & Austin Cr.; Sudden Valley (WH) & N48.71297 W122.33139 & 147 & 17 \\
\hline$* \mathrm{D}$ & Porter Cr. on Mosquito Lk. Rd. (WH) & N48.79416 W122.11621 & 149 & 17 \\
\hline$* \mathrm{~B}$ & Middle F Nooksack; Mosquito Rd. (WH) & N48.78483 W122.11246 & 152 & 16 \\
\hline$* \mathrm{D}$ & Damnation Cr. (Mi. 115) Hwy. 20 (SK) & N48.62717 W121.33821 & 157 & 16 \\
\hline A & Silver Lake (WH) & N48.97137 W122.06909 & 157 & 25 \\
\hline B & Bog pond (Mi. 6.1); Mosquito Rd. (WH) & N48.78022 W122.11444 & 161 & 17 \\
\hline $\mathrm{C}^{\mathbf{l}}$ & Maple Cr. (Mi. 26.1) Hwy. 542 (WH) & N48.92134 W122.07188 & 165 & 16 \\
\hline$* \mathrm{~B}$ & N. Fork Nooksack (Mi. 27) (WH) & N48.92027 W122.06338 & 168 & 15 \\
\hline $\mathrm{D}$ & Hutchinson Cr.; Mosquito Rd. (WH) & N48.74097 W122.12128 & 174 & 15 \\
\hline $\mathrm{C}^{1}$ & Saar Cr. on South Pass Rd. (WH) & N48.96306 W122.18544 & 183 & 18 \\
\hline$* \mathrm{C}^{2}$ & Boulder Cr. (Mi. 26.6) Hwy. 542 (WH) & N48.92772 W122.03107 & 194 & 15 \\
\hline $\mathrm{D}$ & Stream on Mosquito Lk. Rd. (WH) & N48.74098 W122.12155 & 201 & 16 \\
\hline $\mathbf{A}$ & Mosquito Lake Mosquito Lk. Rd. (WH) & N48.76881 W122.11814 & 203 & 17 \\
\hline $\mathbf{A}$ & Toad Lake, Bellingham WA (WH) & N48.79067 W122.39366 & 217 & 22 \\
\hline$* \mathrm{~B}$ & Sol Duc River near Fish Hatchery (CLA) & N48.06066 W124.12282 & 233 & 15 \\
\hline$* \mathrm{~A}$ & Columbia River $(\mathrm{CH})$ & N48.53549 W120.29815 & 248 & 21 \\
\hline$* \mathrm{~A}$ & Okanogan River (OK) & N48.35345 W119.59373 & 260 & 23 \\
\hline$* \mathrm{E}$ & Cornell Cr. (Mi. 32.5) Hwy. 542 (WH) & N48.89208 W121.96208 & 263 & 15 \\
\hline $\mathrm{D}$ & Sulpher Cr. (Mi. 13.3) Baker Lk. Rd. (WH) & N48.65962 W121.71178 & 269 & 15 \\
\hline B & Glacier Cr. on Hwy. $542(\mathrm{WH})$ & N48.88889 W121.94097 & 272 & 14 \\
\hline$* \mathrm{D}$ & Gallop Cr. on Hwy. 542 (WH) & N48.88921 W121.94331 & 274 & 16 \\
\hline $\mathrm{D}$ & Bear Cr. (Mi. 9.5) Baker Lk. Rd. (SK) & N48.62027 W121.74832 & 287 & 17 \\
\hline$* \mathrm{~B}$ & N. Fork Nooksack Hwy. $542(\mathrm{WH})$ & N48.90183 W121.91176 & 292 & 14 \\
\hline$* \mathrm{~B}$ & Bechler River on FS 65 River RD $(\mathrm{CH})$ & N47.72789 W121.33824 & 304 & 16 \\
\hline$* \mathrm{D}$ & Thompson Cr. on FS $39(\mathrm{WH})$ & N48.87905 W121.91206 & 324 & 16 \\
\hline $\mathrm{E}$ & Wall seep (Mi. 125.1) Hwy. 20 (WH) & $\mathrm{N} 48.69190 \mathrm{~W} 121.22426$ & 337 & 15 \\
\hline$* \mathrm{C}^{2}$ & Stream (Mi. 123.5) Hwy. 20 (SK) & $48^{\circ} 69085 \mathrm{~N}, 121^{\circ} 22611 \mathrm{~W}$ & 341 & 16 \\
\hline $\mathrm{E}$ & Stream/falls (Mi. 124) Hwy. 20 (WH) & $48^{\circ} 69102 \mathrm{~N}, 121^{\circ} 22563 \mathrm{~W}$ & 353 & 16 \\
\hline$* \mathrm{D}$ & Falls Cr. on FS38 $(\mathrm{WH})$ & N48.75477 W121.97300 & 369 & 15 \\
\hline $\mathrm{D}$ & Clearwater Cr. on FS $38(\mathrm{WH})$ & N48.74640 W121.94625 & 373 & 15 \\
\hline$* \mathrm{~B}$ & Cascade River 0.9 mi. on FS 1550 (SK) & N48.50134 W121.25027 & 377 & 16 \\
\hline $\mathrm{D}$ & Wall seep on FS Rd. 1550 (SK) & $\mathrm{N} 48.50134 \mathrm{~W} 121.25027$ & 377 & 16 \\
\hline A & Pond on Baker Lake Rd. (WH) & N48.72526 W121.73040 & 381 & 24 \\
\hline$* \mathrm{~B}$ & Skykomish River (Mi. 54.8) Hwy. 2 (KIN) & N47.71184 W121.31284 & 385 & 16 \\
\hline$* \mathrm{C}^{2}$ & Mill Cr. Hwy. $97(\mathrm{CH})$ & N47.51102 W120.63229 & 421 & 19 \\
\hline$* \mathrm{C}^{2}$ & Wenatchee River (Mi. 96.5) Hwy. $2(\mathrm{CH})$ & N47.59482 W120.71292 & 422 & 16 \\
\hline$* \mathrm{C}^{2}$ & Monogram Cr. on Cascade Hwy. (SK) & N48.53565 W121.27194 & 429 & 9 \\
\hline $\mathrm{D}$ & N. Fork Nooksack River at Falls (WH) & N48.90561 W121.80847 & 458 & 15 \\
\hline$* \mathrm{D}$ & Trib near Nooksack Falls (WH) & N48.90657 W121.80682 & 469 & 16 \\
\hline$* \mathrm{C}^{2}$ & Stream (Mi. 40.1) Hwy. 542 (WH) & N48.90785 W121.81145 & 474 & 15 \\
\hline$* \mathrm{C}^{2}$ & Twisp River near Twisp $(\mathrm{OK})$ & N48.36965 W120.14859 & 500 & 18 \\
\hline$* \mathrm{C}^{2}$ & Wenatchee River (Mi. 90.5) Hwy. $2(\mathrm{CH})$ & N47.76895 W120.80300 & 506 & 16 \\
\hline $\mathrm{D}$ & Talapus Cr.; NSF RD 9030 (KIN) & N47.39747 W121.53539 & 522 & 16 \\
\hline $\mathrm{E}$ & Stream (Mi. 40.9) Hwy. $542($ WH) & $48^{\circ} 90793 \mathrm{~N} ; 121^{\circ} 80636 \mathrm{~W}$ & 522 & 15 \\
\hline $\begin{array}{l}\mathrm{L} \\
* \mathrm{C}^{2}\end{array}$ & Chewuch River in Winthrop WA (OK) & N48.48010 W120.18144 & 537 & 16 \\
\hline $\mathrm{C}^{1}$ & Beaver Cr. (Mi. 205.9) Hwy. 20 (OK) & N48.34903 W120.04261 & 541 & 18 \\
\hline $\mathrm{E}$ & Stream/falls (Mi. 41.6) Hwy. $542(\mathrm{WH})$ & N48.90879 W121.80725 & 558 & 14 \\
\hline$* \mathrm{C}^{2}$ & Confluence of Ruby \& Granite Cr. (WH) & N48.70691 W120.91772 & 573 & 15 \\
\hline $\mathrm{E}$ & Stream (Mi. 42.8) Hwy. $542(\mathrm{WH})$ & N48.91127 W121.79332 & 574 & 16 \\
\hline
\end{tabular}




\begin{tabular}{|c|c|c|c|c|c|c|c|}
\hline $\begin{array}{c}\mathrm{TP} \\
\left(\mu \mathrm{g} \cdot \mathrm{L}^{-1}\right)\end{array}$ & $\begin{array}{c}\mathrm{TN} \\
\left(\mu \mathrm{g} \cdot \mathrm{L}^{-1}\right)\end{array}$ & $\begin{array}{c}\mathrm{SPCO} \\
\left(\mathrm{mS} \cdot \mathrm{cm}^{-1}\right)\end{array}$ & $\begin{array}{c}\text { CAN } \\
(\%)\end{array}$ & $\begin{array}{c}\mathrm{EMBE} \\
(\%)\end{array}$ & $\begin{array}{c}\text { SUSE } \\
\left(\mathrm{mg} \cdot \mathrm{L}^{-1}\right)\end{array}$ & RICH & $\mathrm{H}^{\prime}$ \\
\hline 4 & 73 & 0.100 & 70 & 15 & 1 & 23 & 2.84 \\
\hline 5 & 255 & 0.065 & 80 & 10 & 2 & 16 & 2.37 \\
\hline 5 & 120 & 0.073 & 20 & 20 & 5 & 36 & 4.16 \\
\hline 16 & 460 & 0.137 & 75 & 20 & 2 & 34 & 3.87 \\
\hline 7 & 586 & 0.203 & 25 & 80 & 2 & 38 & 4.75 \\
\hline 17 & 77 & 0.070 & 5 & 40 & 2 & 31 & 3.52 \\
\hline 4 & 79 & 0.100 & 75 & 35 & 1 & 24 & 3.10 \\
\hline 4 & 92 & 0.032 & 85 & 15 & 1 & 29 & 2.36 \\
\hline 15 & 145 & 0.016 & 90 & 5 & 8 & 25 & 2.96 \\
\hline 14 & 239 & 0.087 & 35 & 25 & 1 & 58 & 4.14 \\
\hline 12 & 343 & 0.055 & 10 & 95 & 1 & 37 & 4.45 \\
\hline 18 & 956 & 0.069 & 85 & 55 & 1 & 37 & 4.45 \\
\hline 14 & 1016 & 0.050 & 90 & 55 & 1 & 40 & 1.97 \\
\hline 12 & 444 & 0.149 & 90 & 10 & 1 & 30 & 3.23 \\
\hline 4 & 188 & 0.050 & 15 & 10 & 1 & 28 & 3.93 \\
\hline 7 & 89 & 0.100 & 10 & 10 & 50 & 20 & 3.36 \\
\hline 4 & 94 & 0.040 & 20 & 20 & 5 & 36 & 2.86 \\
\hline 9 & 225 & 0.144 & 5 & 80 & 1 & 42 & 4.40 \\
\hline 48 & 551 & 0.127 & 15 & 95 & 5 & 37 & 3.49 \\
\hline 4 & 855 & 0.192 & 10 & 10 & 7 & 62 & 4.31 \\
\hline 11 & 48 & 0.060 & 5 & 20 & 18 & 25 & 3.24 \\
\hline 11 & 268 & 0.092 & 95 & 10 & 1 & 21 & 2.79 \\
\hline 6 & 605 & 0.152 & 85 & 20 & 1 & 33 & 3.67 \\
\hline 7 & 160 & 0.110 & 5 & 5 & 15 & 34 & 2.28 \\
\hline 12 & 437 & 0.085 & 85 & 25 & 1 & 32 & 3.44 \\
\hline 48 & 551 & 0.128 & 5 & 95 & 1 & 29 & 2.70 \\
\hline 9 & 934 & 0.114 & 10 & 80 & 2 & 47 & 4.37 \\
\hline 5 & 74 & 0.105 & 30 & 25 & 1 & 38 & 4.13 \\
\hline 16 & 149 & 0.137 & 0 & 90 & 10 & 83 & 4.76 \\
\hline 23 & 217 & 0.230 & 0 & 85 & 25 & 75 & 4.03 \\
\hline 4 & 113 & 0.050 & 60 & 5 & 2 & 26 & 3.30 \\
\hline 29 & 190 & 0.090 & 90 & 15 & 1 & 41 & 4.17 \\
\hline 38 & 61 & 0.065 & 5 & 15 & 325 & 31 & 2.70 \\
\hline 11 & 301 & 0.060 & 45 & 15 & 1 & 22 & 2.38 \\
\hline 5 & 137 & 0.070 & 75 & 25 & 2 & 30 & 3.69 \\
\hline 22 & 89 & 0.070 & 40 & 20 & 16 & 34 & 4.12 \\
\hline 18 & 30 & 0.027 & 30 & 5 & 7 & 34 & 3.91 \\
\hline 29 & 408 & 0.080 & 95 & 10 & 1 & 26 & 3.83 \\
\hline 4 & 64 & 0.066 & 50 & 5 & 1 & 17 & 2.44 \\
\hline 4 & 46 & 0.050 & 50 & 20 & 1 & 31 & 3.24 \\
\hline 4 & 75 & 0.062 & 20 & 10 & 1 & 18 & 2.62 \\
\hline 9 & 231 & 0.070 & 95 & 5 & 1 & 16 & 2.25 \\
\hline 7 & 68 & 0.064 & 5 & 5 & 5 & 16 & 2.67 \\
\hline 41 & 63 & 0.027 & 20 & 10 & 5 & 20 & 3.10 \\
\hline 25 & 14 & 0.169 & 90 & 25 & 1 & 14 & 1.85 \\
\hline 22 & 646 & 0.058 & 20 & 90 & 1 & 25 & 3.63 \\
\hline 16 & 35 & 0.025 & 5 & 10 & 5 & 22 & 3.56 \\
\hline 9 & 19 & 0.147 & 15 & 10 & 1 & 42 & 4.12 \\
\hline 19 & 94 & 0.026 & 5 & 10 & 16 & 43 & 4.17 \\
\hline 5 & 273 & 0.033 & 95 & 10 & 1 & 37 & 3.75 \\
\hline 22 & 64 & 0.036 & 20 & 65 & 5 & 32 & 3.72 \\
\hline 20 & 40 & 0.080 & 85 & 20 & 1 & 36 & 2.93 \\
\hline 7 & 67 & 0.130 & 80 & 20 & 1 & 36 & 3.24 \\
\hline 8 & 173 & 0.144 & 40 & 40 & 5 & 67 & 4.98 \\
\hline 18 & 90 & 0.027 & 5 & 10 & 20 & 38 & 3.17 \\
\hline 8 & 99 & 0.040 & 95 & 5 & 1 & 32 & 3.43 \\
\hline 5 & 51 & 0.074 & 90 & 15 & 19 & 23 & 3.24 \\
\hline 7 & 98 & 0.120 & 25 & 15 & 1 & 66 & 4.93 \\
\hline 53 & 240 & 0.133 & 35 & 30 & 8 & 32 & 4.30 \\
\hline 4 & 22 & 0.060 & 15 & 10 & 1 & 20 & 2.83 \\
\hline 4 & 29 & 0.026 & 65 & 5 & 1 & 32 & 3.38 \\
\hline 4 & 8 & 0.131 & 10 & 5 & 1 & 24 & 3.15 \\
\hline
\end{tabular}


APPENDIX 1. Continued.

\begin{tabular}{|c|c|c|c|c|}
\hline $\begin{array}{c}\text { Cluster } \\
\text { letter }\end{array}$ & SITE & LOCATION & $\begin{array}{l}\text { ALTI } \\
(\mathrm{m})\end{array}$ & $\begin{array}{c}\text { MTEM } \\
\left({ }^{\circ} \mathrm{C}\right)\end{array}$ \\
\hline$* \mathrm{~B}$ & Chiwaukum Cr. (Mi. 89.9) (Hwy. 2) (CH) & $\mathrm{N} 47.72320 \mathrm{~W} 120.73655$ & 574 & 16 \\
\hline $\mathrm{B}$ & Skinny Cr. (Mi. 88.5) Hwy. 2 (CH) & N47.73061 W120.73897 & 574 & 17 \\
\hline$* \mathrm{~B}$ & N. Fork Nooksack Hwy. $542(\mathrm{WH})$ & N48.91236 W121.78424 & 592 & 14 \\
\hline$* \mathrm{C}^{2}$ & Cle Elum River I-90 (KIT) & N47.18411 W121.00428 & 599 & 17 \\
\hline $\mathrm{E}$ & N. Fork Nooksack; Hannegan Pass (WH) & N48.90588 W121.69389 & 608 & 14 \\
\hline $\mathrm{E}$ & Swamp Cr.; Hannegan Pass Rd. (WH) & N48.90561 W121.68723 & 609 & 14 \\
\hline $\mathrm{E}$ & Stream (Mi. 46.2) Hwy. 542 (WH) & N48.91100 W121.76732 & 610 & 14 \\
\hline$* \mathrm{C}^{1}$ & Teanaway River (Hwy. 970) (KIT) & N47.19562 W120.78508 & 614 & 23 \\
\hline$* \mathrm{C}^{2}$ & Big Cr. on Nelson Siding Rd. (KIT) & N47.20397 W121.11251 & 618 & 16 \\
\hline$* \mathrm{C}^{2}$ & Yakima River (Mi. 79.1) I-90 (KIT) & N47.18580 W121.04352 & 620 & 17 \\
\hline $\mathrm{C}^{2}$ & Stream 1.2 mi. on Hannegan Pass $(\mathrm{WH})$ & N48.90304 W121.67 & 634 & 14 \\
\hline$* \mathrm{C}^{2}$ & Nason Cr. (Mi. 81.4) Hwy. 2 (CH) & N47.76910 W120.80270 & 644 & 15 \\
\hline $\mathrm{C}^{2}$ & Lower Goat Cr.; Goat Cr. Rd. (OK) & N48.58104 W120.37939 & 660 & 16 \\
\hline$* \mathrm{C}^{2}$ & Methow River at Mazama WA $(\mathrm{OK})$ & N48.59052 W120.40689 & 664 & 16 \\
\hline $\mathrm{C}^{1}$ & Loup Loup Cr. (Mi. 222.2) Hwy. 20 (OK) & N48.36698 W119.72832 & 664 & 15 \\
\hline$* \mathrm{C}^{2}$ & Early Winter Cr. Hwy. 20 (OK) & N48.59790 W120.44338 & 669 & 15 \\
\hline$* \mathrm{E}$ & Varden Cr. (Mi. 173.1) Hwy. 20 (OK) & N48.58836 W120.49825 & 675 & 14 \\
\hline$* \mathrm{C}^{2}$ & Upper Goat Cr. (FS 52) (OK) & N48.59038 W120.37012 & 686 & 15 \\
\hline$* \mathrm{C}^{2}$ & Boulder Cr. on FS37 near Winthrop (OK) & N48.58300 W120.14850 & 694 & 16 \\
\hline $\mathrm{C}^{2-}$ & Stream (Mi. 48.1) Hwy. $542(\mathrm{WH})$ & N48.88998 W121.67530 & 712 & 15 \\
\hline B & Barr Cr. (Mi. 4.4) FS33 (WH) & N48.86704; W121.76761 & 715 & 13 \\
\hline $\mathrm{E}$ & Wells Cr. (Mi. 4.4) FS33 (WH) & N48.86718; W121.76630 & 718 & 13 \\
\hline $\mathrm{E}$ & Wall seep; Wells Cr. (Mi. 4.4) F33 (WH) & N48.86736; W121.76635 & 729 & 13 \\
\hline $\mathrm{E}$ & Wall seep (Mi. 47.6) Hwy. $542($ WH) & N48.88854; W121.67356 & 734 & 15 \\
\hline $\mathrm{E}$ & Wall seep (Mi. 48.6) Hwy. 542 (WH) & N48.88758 W121.67236 & 741 & 15 \\
\hline $\mathrm{E}$ & Stream/falls (Mi. 144.3) Hwy. 20 (SK) & N48.68110 W120.88167 & 763 & 14 \\
\hline $\mathrm{E}$ & Bagley Cr. (Mi. 49.1) Hwy. 542 (WH) & N48.87708 W121.67064 & 822 & 14 \\
\hline $\mathrm{C}^{1}$ & Frazer Cr. (Mi. 210.3) Hwy. $20(\mathrm{OK})$ & N48.36466 W120.01267 & 848 & 15 \\
\hline $\mathrm{E}$ & Lower Galena Cr. Hwy. 542 (WH) & N48.87028 W121.6651 & 921 & 14 \\
\hline $\mathrm{E}$ & Commonwealth Cr. (KIT) & N47.42945 W121.42017 & 922 & 16 \\
\hline $\mathrm{E}$ & Ruth Cr. at Ruth Cr. campground (WH) & N48.90943 W121.59166 & 934 & 13 \\
\hline $\mathrm{C}^{2}$ & Swauk Cr. (Mi. 159.7) Hwy. 97 (KIT) & N47.24250 W120.69739 & 944 & 15 \\
\hline $\mathrm{E}$ & Wall seep (Mi. 52.1) Hwy. 542 (WH) & N48.85164 W121.68526 & 1051 & 14 \\
\hline $\mathrm{E}$ & Jack Cr. (Mi. 213.9) Hwy. 20 (OK) & N48.36783 W120.00336 & 1117 & 14 \\
\hline B & Pond (Mi. 53.1) Hwy. 542 (WH) & $48^{\circ} 51953 \mathrm{~N}, 121^{\circ} 39965 \mathrm{~W}$ & 1167 & 14 \\
\hline $\mathrm{E}$ & Wall seep (Mi. 54) Hwy. 542 (WH) & N48.86222 W121.67215 & 1229 & 14 \\
\hline $\mathrm{B}$ & Highwood Lake; Mt. Baker (WH) & N48.86513 W121.67473 & 1238 & 21 \\
\hline $\mathrm{E}$ & Cutthroat Cr. Mi. 167 Hwy. 20 bridge (OK) & N48.54965 W120.66954 & 1242 & 12 \\
\hline B & Picture Lake; Mt. Baker (WH) & N48.86565 W121.67627 & 1317 & 19 \\
\hline $\mathrm{E}$ & Stream on Fire \& Ice trail $(\mathrm{WH})$ & N48.85586 W121.68795 & 1329 & 13 \\
\hline $\mathrm{E}$ & Stream near Heather Info Center $(\mathrm{WH})$ & N48.85507 W121.68295 & 1343 & 16 \\
\hline B & Terminal Lake; Mt. Baker (WH) & $\mathrm{N} 48.85315,121^{\circ} 68473 \mathrm{~W}$ & 1344 & 18 \\
\hline $\mathrm{E}$ & Wall seep at Artist Point Hwy. (WH) & N48.85177 W121.68473 & 1381 & 13 \\
\hline $\mathrm{E}$ & Early Winter Cr. Headwaters (WH) & N48.52873 W120.64003 & 1410 & 13 \\
\hline $\mathrm{E}$ & Bridge Cr. (Mi. 158.7) Hwy. $20(\mathrm{CH})$ & $\mathrm{N} 48^{\circ} 30.29 \mathrm{~W} 120^{\circ} 43.16$ & 1414 & 13 \\
\hline
\end{tabular}




\begin{tabular}{|c|c|c|c|c|c|c|c|}
\hline $\begin{array}{c}\text { TP } \\
\left(\mu \mathrm{g} \cdot \mathrm{L}^{-1}\right)\end{array}$ & $\begin{array}{c}\text { TN } \\
\left(\mu \mathrm{g} \cdot \mathrm{L}^{-1}\right)\end{array}$ & $\begin{array}{c}\mathrm{SPCO} \\
\left(\mathrm{mS} \cdot \mathrm{cm}^{-1}\right)\end{array}$ & $\begin{array}{l}\text { CAN } \\
(\%)\end{array}$ & $\begin{array}{c}\mathrm{EMBE} \\
(\%)\end{array}$ & $\begin{array}{l}\text { SUSE } \\
\left(\mathrm{mg} \cdot \mathrm{L}^{-1}\right)\end{array}$ & RICH & $\mathrm{H}^{\prime}$ \\
\hline 29 & 157 & 0.029 & 45 & 5 & 1 & 37 & 2.90 \\
\hline 5 & 101 & 0.208 & 0 & 35 & 16 & 28 & 4.26 \\
\hline 29 & 67 & 0.033 & 10 & 15 & 15 & 37 & 4.27 \\
\hline 10 & 61 & 0.051 & 5 & 10 & 5 & 39 & 4.44 \\
\hline 20 & 53 & 0.029 & 5 & 5 & 1 & 26 & 4.00 \\
\hline 4 & 55 & 0.076 & 10 & 35 & 5 & 19 & 3.38 \\
\hline 6 & 10 & 0.141 & 5 & 5 & 1 & 20 & 3.11 \\
\hline 51 & 207 & 0.162 & 5 & 20 & 5 & 41 & 1.98 \\
\hline 16 & 35 & 0.090 & 90 & 20 & 1 & 33 & 4.11 \\
\hline 16 & 108 & 0.065 & 35 & 10 & 10 & 57 & 4.20 \\
\hline 4 & 46 & 0.062 & 5 & 5 & 1 & 23 & 2.79 \\
\hline 15 & 35 & 0.038 & 25 & 10 & 5 & 51 & 4.28 \\
\hline 5 & 25 & 0.099 & 10 & 5 & 5 & 40 & 4.58 \\
\hline 4 & 28 & 0.090 & 25 & 5 & 5 & 44 & 4.15 \\
\hline 61 & 166 & 0.188 & 30 & 15 & 1 & 49 & 3.47 \\
\hline 4 & 29 & 0.070 & 10 & 5 & 5 & 57 & 4.09 \\
\hline 4 & 17 & 0.042 & 5 & 5 & 1 & 27 & 3.12 \\
\hline 5 & 20 & 0.061 & 5 & 5 & 1 & 28 & 4.31 \\
\hline 6 & 78 & 0.080 & 10 & 5 & 1 & 47 & 3.92 \\
\hline 4 & 19 & 0.066 & 75 & 5 & 1 & 38 & 3.80 \\
\hline 12 & 83 & 0.147 & 0 & 15 & 785 & 15 & 2.56 \\
\hline 9 & 44 & 0.060 & 5 & 10 & 1 & 26 & 2.46 \\
\hline 4 & 83 & 0.205 & 75 & 20 & 1 & 30 & 2.99 \\
\hline 4 & 83 & 0.104 & 5 & 5 & 1 & 19 & 2.53 \\
\hline 4 & 38 & 0.168 & 20 & 10 & 1 & 13 & 1.57 \\
\hline 4 & 51 & 0.034 & 20 & 5 & 1 & 27 & 3.13 \\
\hline 8 & 106 & 0.033 & 95 & 5 & 1 & 30 & 3.11 \\
\hline 51 & 180 & 0.161 & 95 & 15 & 3 & 63 & 4.74 \\
\hline 4 & 56 & 0.023 & 80 & 20 & 1 & 23 & 3.20 \\
\hline 21 & 123 & 0.283 & 75 & 20 & 1 & 33 & 3.29 \\
\hline 4 & 91 & 0.022 & 75 & 5 & 1 & 20 & 3.19 \\
\hline 38 & 28 & 0.246 & 95 & 25 & 5 & 43 & 3.99 \\
\hline 8 & 73 & 0.034 & 50 & 75 & 1 & 11 & 2.13 \\
\hline 30 & 194 & 0.108 & 95 & 5 & 1 & 29 & 3.22 \\
\hline 20 & 248 & 0.152 & 10 & 90 & 1 & 36 & 4.53 \\
\hline 5 & 117 & 0.016 & 25 & 5 & 1 & 21 & 2.47 \\
\hline 15 & 163 & 0.037 & 0 & 95 & 1 & 31 & 3.90 \\
\hline 4 & 25 & 0.010 & 90 & 5 & 1 & 24 & 3.11 \\
\hline 8 & 164 & 0.062 & 0 & 90 & 1 & 36 & 3.95 \\
\hline 11 & 30 & 0.025 & 0 & 5 & 1 & 37 & 4.00 \\
\hline 4 & 0.8 & 0.006 & 0 & 5 & 1 & 21 & 3.00 \\
\hline 13 & 130 & 0.013 & 0 & 75 & NA & 31 & 3.83 \\
\hline 10 & 21 & 0.004 & 0 & 5 & 0 & 12 & 1.99 \\
\hline 8 & 19 & 0.009 & 0 & 5 & 0 & 15 & 3.15 \\
\hline 4 & 42 & 0.030 & 10 & 5 & 1 & 26 & 3.43 \\
\hline
\end{tabular}


APPEndix 2. Diatom species collected in northwestern Washington, including the Olympic Pennisula. Total $=415$ species; 352 river/stream; 213 pond and lake.

\begin{tabular}{|c|c|c|}
\hline Species & Stream/river & Lake and pond \\
\hline Achnanthes grischuna Wuthrich & $\mathrm{x}$ & \\
\hline Achnanthes nitidiformis Lange-Bertalot & & $\mathrm{x}$ \\
\hline Achnanthes rupestoides Hohn & & $\mathrm{x}$ \\
\hline Achnanthes rupestris Krasske & $\mathrm{x}$ & \\
\hline Achnanthes stolida Krasske & & $\mathrm{x}$ \\
\hline Achnanthes subsalsa Petersen & $\mathrm{x}$ & \\
\hline Achnanthidium affine (Grun.) Czar. & $\mathrm{x}$ & \\
\hline Achnanthidium biasolettianum (Grun.) Round \& Bukht. & $\mathrm{x}$ & $\mathrm{x}$ \\
\hline Achnanthidium exiguum (Grun.) Czar. & $\mathrm{x}$ & \\
\hline Achnanthidium exile (Kütz.) Heiberg & $\mathrm{x}$ & \\
\hline Achnanthidium gracillimum (Meister) Lange-Bertalot & & $\mathrm{x}$ \\
\hline Achnanthidium jackii Rabh. & $\mathrm{x}$ & \\
\hline Achnanthidium minutissimum (Kütz.) Czar. & & $\mathrm{x}$ \\
\hline Adlafia bryophila (Petersen) Moser, Lange-Bertalot \& Metzeltin & & $\mathrm{x}$ \\
\hline Adlafia miniscula (Grun.) Lange-Bertalot & $\mathrm{x}$ & \\
\hline Adlafia miniscula v. muralis (Grun.) Lange-Bertalot & $\mathrm{x}$ & \\
\hline Amphipleura lindheimeri Grun. & $\mathrm{x}$ & \\
\hline Amphipleura pellucida (Kütz.) Kütz. & $\mathrm{x}$ & \\
\hline Amphora ovalis (Kütz.) Kütz. & & $\mathrm{x}$ \\
\hline Amphora pediculus (Kütz.) Grun. ex A. Schmidt & & $\mathrm{x}$ \\
\hline Anomoeoneis brachysira (Bréb) Grun. & & $\mathrm{x}$ \\
\hline Anomoeoneis sphaerophora E. Pfitzer & $\mathrm{x}$ & \\
\hline Anomoeoneis styriaca (Grun.) Hust. & $\mathrm{x}$ & \\
\hline Anomoeoneis vitrea (Grun.) Ross & & $\mathrm{x}$ \\
\hline Asterionella formosa Hass. & $\mathrm{x}$ & \\
\hline Aulacoseira alpigina (Grun.) Krammer & $\mathrm{x}$ & $\mathrm{x}$ \\
\hline Aulacoseira ambigua (Grun.) Simonsen & & $\mathrm{x}$ \\
\hline Aulacoseira distans (Ehr.) Simonsen & $\mathrm{x}$ & $\mathrm{x}$ \\
\hline Aulacoseira granulata (Ehr.) Simonsen & $\mathrm{x}$ & $\mathrm{x}$ \\
\hline Aulacoseira islandica (Müller) Simonsen & $\mathrm{x}$ & $\mathrm{x}$ \\
\hline Aulacoseira italica (Ehr.) Simonsen & $\mathrm{x}$ & \\
\hline Aulacoseira italica v. tenuissima (Grun.) Simonsen & $\mathrm{x}$ & \\
\hline Aulacoseira valida (Grun.) Krammer & & $\mathrm{x}$ \\
\hline Bacillaria paradoxa Gmelin & & $\mathrm{x}$ \\
\hline Biddulphia laevis Ehr. & $\mathrm{x}$ & \\
\hline Brachysira brebissonii Ross & $\mathrm{x}$ & \\
\hline Caloneis alpestris (Grun.) Cl. & $\mathrm{x}$ & \\
\hline Caloneis bacillum (Grun.) Cl. & $\mathrm{x}$ & $\mathrm{x}$ \\
\hline Caloneis latiuscula (Kütz.) Cl. & & $\mathrm{x}$ \\
\hline Caloneis molaris (Grun.) Krammer & $\mathrm{x}$ & \\
\hline Caloneis permagna (Bailey) $\mathrm{Cl}$. & $\mathrm{x}$ & \\
\hline Caloneis pulchra Messikommer & $\mathrm{x}$ & \\
\hline Caloneis schumanniana (Grun.) Cl. & $\mathrm{x}$ & \\
\hline Caloneis silicula (Ehr.) Cl. & $\mathrm{x}$ & $\mathrm{x}$ \\
\hline Caloneis sublinearis (Grun.) Krammer & $\mathrm{x}$ & \\
\hline Caloneis tenuis (Greg.) Krammer & $\mathrm{x}$ & \\
\hline Caloneis undulata (Greg.) Krammer & $\mathrm{x}$ & \\
\hline Caloneis westii (W. Sm.) Hendy & $\mathrm{x}$ & \\
\hline Campylodiscus clypeus (Ehr.) Ehr. ex Kütz. & $\mathrm{x}$ & \\
\hline Cocconeis neodiminuta Krammer & $\mathrm{x}$ & \\
\hline Cocconeis pediculus Ehr. & $\mathrm{x}$ & \\
\hline Cocconeis placentula Ehr. & $\mathrm{x}$ & $\mathrm{x}$ \\
\hline Cocconeis placentula v. euglypta (Ehr.) Grun. & $\mathrm{x}$ & \\
\hline Cocconeis placentula f. lineata (Ehr.) Van Heurck & $\mathrm{x}$ & \\
\hline Cocconeis scutellum Ehr. & $\mathrm{x}$ & \\
\hline Craticula cuspidata (Kütz.) Mann & & $\mathrm{x}$ \\
\hline Craticula halophila (Grun.) Mann & & $\mathrm{x}$ \\
\hline Ctenophora pulchella (Ralfs. ex Kütz.) Williams \& Round & & $\mathrm{x}$ \\
\hline Cyclotella atomus Hust. & & $\mathrm{x}$ \\
\hline Cyclotella distinguenda Hust. & $\mathrm{x}$ & \\
\hline Cyclotella hakanssoniae Wendker & $\mathrm{x}$ & \\
\hline Cyclotella menghiniana Kütz. & $\mathrm{x}$ & $\mathrm{x}$ \\
\hline
\end{tabular}


APPENDIX 2. Continued.

\begin{tabular}{|c|c|c|}
\hline Species & Stream/river & Lake and pond \\
\hline Cyclotella michiganana Skvortzow & & $\mathrm{x}$ \\
\hline Cyclotella planctonica Brunnthaler & $\mathrm{x}$ & \\
\hline Cymatopleura solea (Bréb.) W. Sm. & $\mathrm{x}$ & \\
\hline Cymbella aequalis W. Sm. & & $\mathrm{x}$ \\
\hline Cymbella affinis Kütz. & $\mathrm{x}$ & $\mathrm{x}$ \\
\hline Cymbella aspera (Ehr.) Cl. & $\mathrm{x}$ & $\mathrm{x}$ \\
\hline Cymbella austriaca Grun. & $\mathrm{x}$ & $\mathrm{x}$ \\
\hline Cymbella caespitosa (Kütz.) Brun & & $\mathrm{x}$ \\
\hline Cymbella cesatii (Rabh.) Grun. & $\mathrm{x}$ & \\
\hline Cymbella cistula (Hemprich \& Ehr.) Kirchner & $\mathrm{x}$ & $\mathrm{x}$ \\
\hline Cymbella cuspidata Kütz. & $\mathrm{x}$ & \\
\hline Cymbella cymbiformis C. Ag. & $\mathrm{x}$ & $\mathrm{x}$ \\
\hline Cymbella cymbiformis v. nonpunctata Fontell & $\mathrm{x}$ & \\
\hline Cymbella delicatula (Kütz.) Krammer & $\mathrm{x}$ & \\
\hline Cymbella ehrenbergii Kütz. & $\mathrm{x}$ & \\
\hline Cymbella hauckii Van Heurck & $\mathrm{x}$ & \\
\hline Cymbella helvetica Kütz. & $\mathrm{x}$ & $\mathrm{x}$ \\
\hline Cymbella hungarica (Grun.) Pantocsek & $\mathrm{x}$ & \\
\hline Cymbella hybrida Grun. ex Cl. & & $\mathrm{x}$ \\
\hline Cymbella incerta (Grun.) Krammer & & $\mathrm{x}$ \\
\hline Cymbella incerta v. crassipunctata Krammer & & $\mathrm{x}$ \\
\hline Cymbella janischii (A. Schmidt) De Toni. & $\mathrm{x}$ & \\
\hline Cymbella laevis Nägeli & $\mathrm{x}$ & $\mathrm{x}$ \\
\hline Cymbella lata Grun. ex Cl. & $\mathrm{x}$ & \\
\hline Cymbella mesiana Cholnoky & $\mathrm{x}$ & \\
\hline Cymbella mexicana (Ehr.) Cl. & $\mathrm{x}$ & \\
\hline Cymbella naviculiformis (Auerswald) Cl. & $\mathrm{x}$ & $\mathrm{x}$ \\
\hline Cymbella norvegica Grun. & $\mathrm{x}$ & \\
\hline Cymbella proxima Reimer & & $\mathrm{x}$ \\
\hline Cymbella rainierensis Sov. & $\mathrm{x}$ & \\
\hline Cymbella reinhardtii Grun. & $\mathrm{x}$ & $\mathrm{x}$ \\
\hline Cymbella schimanskii Krammer & $\mathrm{x}$ & \\
\hline Cymbella tumida (Bréb) Van Heurck & $\mathrm{x}$ & \\
\hline Cymbopleura amphicephala (Nageli) Krammer & & $\mathrm{x}$ \\
\hline Cymbopleura naviculiformis (Auerswald ex Heiberg) Krammer & $\mathrm{x}$ & \\
\hline Decussata placenta (Ehr.) Lange-Bertalot & $\mathrm{x}$ & \\
\hline Denticula elegans Kütz & $\mathrm{x}$ & $\mathrm{x}$ \\
\hline Denticula kuetzingii Grun. & $\mathrm{x}$ & \\
\hline Denticula subtilis Grun. & $\mathrm{x}$ & \\
\hline Diatoma anceps (Ehr.) Kirchner & $\mathrm{x}$ & $\mathrm{x}$ \\
\hline Diatoma hyemalis (Roth) Heiberg & $\mathrm{x}$ & \\
\hline Diatoma mesodon (Ehr.) Kütz. & $\mathrm{x}$ & $\mathrm{x}$ \\
\hline Diatoma tenuis C. Ag. & $\mathrm{x}$ & \\
\hline Diatoma vulgaris Bory & $\mathrm{x}$ & $\mathrm{x}$ \\
\hline Diatomella balfouriana Grev. & $\mathrm{x}$ & \\
\hline Didymosphaenia geminata (Lyngbye) M. Schmidt & $\mathrm{x}$ & $\mathrm{x}$ \\
\hline Diploneis elliptica (Kütz.) Cl. & $\mathrm{x}$ & $\mathrm{x}$ \\
\hline Diploneis modica Hust. & & $\mathrm{x}$ \\
\hline Diploneis oblongella (Nägeli ex Kütz.) CL-EU & $\mathrm{x}$ & \\
\hline Diploneis ovalis (Hilse) Cl. & $\mathrm{x}$ & $\mathrm{x}$ \\
\hline Diploneis pseudovalis Hust. & $\mathrm{x}$ & \\
\hline Diploneis puella (Schumann) Cl. & $\mathrm{x}$ & \\
\hline Discotella stelligera (Cl. \& Grun.) Houk \& Klee & $\mathrm{x}$ & $\mathrm{x}$ \\
\hline Encyonema gracile Rabh. & $\mathrm{x}$ & $\mathrm{x}$ \\
\hline Encyonema minutum (Hilse) Mann & $\mathrm{x}$ & $\mathrm{x}$ \\
\hline Encyonema muelleri Hust. & $\mathrm{x}$ & \\
\hline Encyonema prostratum (Berkeley) Kütz. & $\mathrm{x}$ & \\
\hline Encyonema silesiacum (Bleisch) Mann & $\mathrm{x}$ & $\mathrm{x}$ \\
\hline Encyonopsis cesatii (Rabh.) Krammer & $\mathrm{x}$ & $\mathrm{x}$ \\
\hline Encyonopsis descripta (Hust.) Krammer & & $\mathrm{x}$ \\
\hline Encyonopsis falaisensis (Grun.) Krammer & $\mathrm{x}$ & \\
\hline Encyonopsis microcephala (Grun.) Krammer & $\mathrm{x}$ & $\mathrm{x}$ \\
\hline Entomoneis alata (Ehr.) Reimer & $\mathrm{x}$ & \\
\hline
\end{tabular}


APPENDIX 2. Continued.

\begin{tabular}{|c|c|c|}
\hline Species & Stream/river & Lake and pond \\
\hline Entomoneis paludosa (W. Sm.) Reimer & $\mathrm{x}$ & \\
\hline Epithemia adnata (Kütz.) Bréb. & $\mathrm{x}$ & $\mathrm{x}$ \\
\hline Epithemia alpestris (W. Sm.) & $\mathrm{x}$ & \\
\hline Epithemia argus (Ehr.) Kütz. & $\mathrm{x}$ & $\mathrm{x}$ \\
\hline Epithemia sorex Kütz. & $\mathrm{x}$ & $\mathrm{x}$ \\
\hline Epithemia turgida (Ehr.) Kütz. & $\mathrm{x}$ & $\mathrm{x}$ \\
\hline Epithemia turgida v. granulata (Ehr.) Brun & $\mathrm{x}$ & $\mathrm{x}$ \\
\hline Epithemia turgida v. westermannii (Ehr.) Grun. & $\mathrm{x}$ & $\mathrm{x}$ \\
\hline Eucocconeis flexella (Kütz.) Cl. & $\mathrm{x}$ & \\
\hline Eucocconeis laevis (Østrup) Lange-Bertalot & $\mathrm{x}$ & \\
\hline Eunotia arcus Ehr. & $\mathrm{x}$ & $\mathrm{x}$ \\
\hline Eunotia bilunaris (Ehr.) Schaarschmidt & $\mathrm{x}$ & $\mathrm{x}$ \\
\hline $\begin{array}{l}\text { Eunotia bilunaris v. mucophila } \\
\quad \text { (Lange-Bertalot \& Norpel-Schempp) Lange-Bertalot }\end{array}$ & $\mathrm{x}$ & \\
\hline Eunotia diodon Ehr. & $\mathrm{x}$ & $\mathrm{x}$ \\
\hline Eunotia exigua (Bréb.) Rabh. & $\mathrm{x}$ & \\
\hline Eunotia formica (Ehr.) & $\mathrm{x}$ & \\
\hline Eunotia implicata Nörpel, Lange-Bertalot \& Alles & $\mathrm{x}$ & $\mathrm{x}$ \\
\hline Eunotia incisa Smith ex Greg. & $\mathrm{x}$ & $\mathrm{x}$ \\
\hline Eunotia monodon Ehr. & $\mathrm{x}$ & \\
\hline Eunotia muscicola Krasske & $\mathrm{x}$ & \\
\hline Eunotia muscicola v. tridentula Nörpel \& Lange-Bertalot & $\mathrm{x}$ & \\
\hline Eunotia pectinalis (Kütz) Rabh. & $\mathrm{x}$ & $\mathrm{x}$ \\
\hline Eunotia pectinalis v. undulata (Ralfs.) Rabh. & $\mathrm{x}$ & $\mathrm{x}$ \\
\hline Eunotia praerupta Ehr. & $\mathrm{x}$ & \\
\hline Eunotia serra v. diadema (Ehr.) Patrick & & $\mathrm{x}$ \\
\hline Eunotia serra v. tetraodon (Ehr.) CL-EU & $\mathrm{x}$ & \\
\hline Eunotia soleirolii (Kütz) Rabh. & $\mathrm{x}$ & \\
\hline Fallacia pygmaea (Kütz) Stickle \& Mann & $\mathrm{x}$ & \\
\hline Fragilaria capucina Desm. & $\mathrm{x}$ & $\mathrm{x}$ \\
\hline Fragilaria constricta Ehr. & $\mathrm{x}$ & \\
\hline Fragilaria crotonensis Kitton & $\mathrm{x}$ & $\mathrm{x}$ \\
\hline Fragilaria delicatissima (W.Sm.) Lange-Bertalot & $\mathrm{x}$ & \\
\hline Fragilaria familica (Kütz.) Lange-Bertalot & & $\mathrm{x}$ \\
\hline Fragilaria mazamaensis (Sov.) Lange-Bertalot & $\mathrm{x}$ & \\
\hline Fragilaria nanana Lange-Bertalot & & $\mathrm{x}$ \\
\hline Fragilaria pseudoconstruens Marciniak & $\mathrm{x}$ & \\
\hline Fragilaria tenera $($ W. Sm.) Lange-Bertalot & $\mathrm{x}$ & $\mathrm{x}$ \\
\hline Fragilaria vaucheriae (Kütz.) Perersen & $\mathrm{x}$ & $\mathrm{x}$ \\
\hline Fragilaria virescens (Ralfs) Williams \& Round & $\mathrm{x}$ & \\
\hline Frustulia crassinervia (Bréb) Lange-Bertalot \& Krammer & $\mathrm{x}$ & $\mathrm{x}$ \\
\hline Frustulia krammeri Lange-Bertalot \& Metzeltin & $\mathrm{x}$ & $\mathrm{x}$ \\
\hline Frustulia saxonica Rabh. & & $\mathrm{x}$ \\
\hline Frustulia spicula Amossé & & $\mathrm{x}$ \\
\hline Frustulia vulgaris (Thwaites) De Toni & $\mathrm{x}$ & $\mathrm{x}$ \\
\hline Geisslera decussis (Østrup) Lange-Bertaot \& Metzeltin & $\mathrm{x}$ & \\
\hline Geisslera ignota (Krasske) Lange-Bertalot \& Metzeltin & $\mathrm{x}$ & \\
\hline Geisslera schoenfeldii (Hust.) Lange-Bertalot \& Metzeltin & $\mathrm{x}$ & $\mathrm{x}$ \\
\hline Gomphoneis eriense v. varabilis Kociolek \& Stoermer & $\mathrm{x}$ & \\
\hline Gomphoneis herculeana (Ehr.) Cl. & $\mathrm{x}$ & \\
\hline Gomphoneis minuta (Stone) Kociolek and Stoermer & $\mathrm{x}$ & \\
\hline Gomphonema accuminatum Ehr. & $\mathrm{x}$ & $\mathrm{x}$ \\
\hline Gomphonema affine Kütz. & $\mathrm{x}$ & $\mathrm{x}$ \\
\hline Gomphonema angustatum (Kütz.) Rabh. & $\mathrm{x}$ & $\mathrm{x}$ \\
\hline Gomphonema angustum C. Ag. & $\mathrm{x}$ & \\
\hline Gomphonema auger v. sphaerophorum (Ehr.) Grun. & $\mathrm{x}$ & \\
\hline Gomphonema clavatum Ehr. & $\mathrm{x}$ & $\mathrm{x}$ \\
\hline Gomphonema clevei Fricke & $\begin{array}{l}\mathrm{A} \\
\mathrm{x}\end{array}$ & $\mathrm{x}$ \\
\hline Gomphonema gracile Ehr. & $\begin{array}{l}\Delta \\
\mathrm{x}\end{array}$ & \\
\hline Gomphonema hebridense W. Greg. & $\begin{array}{l}\mathrm{x} \\
\mathrm{x}\end{array}$ & \\
\hline Gomphonema kobayasii Kociolek \& Kingston & $\mathrm{x}$ & \\
\hline Gomphonema minutum (C. Ag.) C. Ag. & $\mathrm{x}$ & $\mathrm{x}$ \\
\hline Gomphonema olivaceum (Hornemann) Ehr. & $\mathrm{x}$ & \\
\hline
\end{tabular}


APPENDIX 2. Continued.

\begin{tabular}{|c|c|c|}
\hline Species & Stream/river & Lake and pond \\
\hline Gomphonema olivaceum f. fonticola Hust. & $\mathrm{x}$ & \\
\hline Gomphonema parvulum (Kütz.) Kütz. & $\mathrm{x}$ & $\mathrm{x}$ \\
\hline Gomphonema subtile Ehr. & $\mathrm{x}$ & $\mathrm{x}$ \\
\hline Gomphonema tenellum Kütz. & $\mathrm{x}$ & \\
\hline Gomphonema truncatum Ehr. & $\mathrm{x}$ & $\mathrm{x}$ \\
\hline Gomphonema truncatum v. turgidum (Ehr.) Patr. & $\mathrm{x}$ & \\
\hline Gyrosigma acuminatum (Kütz.) Rabh. & & $\mathrm{x}$ \\
\hline Gyrosigma attenuatum (Kütz.) Rabh & $\mathrm{x}$ & \\
\hline Gyrosigma spencerii (W. Sm) Griffith \& Henfrey & $\mathrm{x}$ & \\
\hline Halamphora coffeaeformis (Ag.) Levkov. & $\mathrm{x}$ & \\
\hline Halamphora veneta (Kütz.) Levkov & & $\mathrm{x}$ \\
\hline Hannaea arcus (Ehr.) Patr. & $\mathrm{x}$ & $\mathrm{x}$ \\
\hline Hantzschia amphioxys (Ehr.) Grun. & $\mathrm{x}$ & \\
\hline Hippodonta capitata (Ehr.) Lange-Bertalot, Metzeltin \& Witkowski & $\mathrm{x}$ & \\
\hline Karayevia oblongella (Østrup) M. Aboal & & $\mathrm{x}$ \\
\hline Karayevia suchlandtii (Hust.) Bukhtiyarova & $\mathrm{x}$ & $\mathrm{x}$ \\
\hline Lemnicola hungarica (Grun.) Round \& Basson & $\mathrm{x}$ & \\
\hline Luticola cohnii (Hilse) Mann & $\mathrm{x}$ & \\
\hline Luticola goeppertiana (Bleisch) Mann & $\mathrm{x}$ & $\mathrm{x}$ \\
\hline Luticola mutica (Kütz.) Mann & $\mathrm{x}$ & \\
\hline Mastogloia braunii Grun. & $\mathrm{x}$ & \\
\hline Mastogloia pumila (Cl. \& Möller, Grun.) Cl. & $\mathrm{x}$ & \\
\hline Melosira varians C. Ag. & $\mathrm{x}$ & \\
\hline Meridion circulare (Grev.) C. Ag. & $\mathrm{x}$ & $\mathrm{x}$ \\
\hline Meridion circulare v. constrictum (Ralfs) Van Heurck & $\mathrm{x}$ & \\
\hline Navicula aboensis (Cl.) Cl. & $\mathrm{x}$ & \\
\hline Navicula abiskoensis Hust. & $\mathrm{x}$ & \\
\hline Navicula angusta Grun. & $\mathrm{x}$ & $\mathrm{x}$ \\
\hline Navicula cari Ehr. & $\mathrm{x}$ & \\
\hline Navicula cincta (Ehr.) Ralfs. & $\mathrm{x}$ & $\mathrm{x}$ \\
\hline Navicula cocconeiformis Greg. ex Greville & & $\mathrm{x}$ \\
\hline Navicula concentrica Carter \& Bailey-Watts & & $\mathrm{x}$ \\
\hline Navicula crucicula (W. Sm.) Donkin & $\mathrm{x}$ & \\
\hline Navicula crucicula v. cruciculoides (Brockman) Lange-Bertalot & $\mathrm{x}$ & \\
\hline Navicula cryptocephala Kütz. & $\mathrm{x}$ & $\mathrm{x}$ \\
\hline Navicula cryptonella Lange-Bertalot & $\mathrm{x}$ & \\
\hline Navicula dentata Hust. & $\mathrm{x}$ & $\mathrm{x}$ \\
\hline Navicula expecta VanLandingham & $\mathrm{x}$ & \\
\hline Navicula gottlandica Grun. & $\mathrm{x}$ & $\mathrm{x}$ \\
\hline Navicula gregaria Donkin & $\mathrm{x}$ & $\mathrm{x}$ \\
\hline Navicula hambergii Hust. & $\mathrm{x}$ & \\
\hline Navicula hasta Pantocsek & $\mathrm{x}$ & \\
\hline Navicula heimansii Van Dam \& Kooyman & $\mathrm{x}$ & $\mathrm{x}$ \\
\hline Navicula insociabilis Krasske & $\mathrm{x}$ & \\
\hline Navicula jaernefeltii Hust. & & $\mathrm{x}$ \\
\hline Navicula lacustris W. Greg. & $\mathrm{x}$ & \\
\hline Navicula lanceolata Ehr. & $\mathrm{x}$ & \\
\hline Navicula leptostriata Jørgensen & & $\mathrm{x}$ \\
\hline Navicula libonensis Schoeman & $\mathrm{x}$ & \\
\hline Navicula margalithii Lange-Bertalot & $\mathrm{x}$ & \\
\hline Navicula menisculus Schumann & $\mathrm{x}$ & $\mathrm{x}$ \\
\hline Navicula molestiformis Hust. & $\mathrm{x}$ & \\
\hline Navicula ordinaria Hust. & & $\mathrm{x}$ \\
\hline Navicula peregrina (Ehr.) Kütz. & $\mathrm{x}$ & \\
\hline Navicula phyllepta Kütz. & $\mathrm{x}$ & \\
\hline Navicula placentula (Ehr.) Grun. & $\mathrm{x}$ & \\
\hline Navicula pseudoscutiformis Hust. & $\mathrm{x}$ & $\mathrm{x}$ \\
\hline Navicula pseudoventralis Hust. & & $\mathrm{x}$ \\
\hline Navicula pusilla v. incognita (Krasske) Lange-Bertalot & $\mathrm{x}$ & \\
\hline Navicula pusio Cl. & & $\mathrm{x}$ \\
\hline Navicula radiosa Kütz. & $\mathrm{x}$ & $\mathrm{x}$ \\
\hline Navicula recens (Lange-Bertalot) Lange-Bertalot & $\mathrm{x}$ & $\mathrm{x}$ \\
\hline Navicula reinhardtii (Grun.) Grun. & $\mathrm{x}$ & \\
\hline
\end{tabular}


APPENDIX 2. Continued.

\begin{tabular}{|c|c|c|}
\hline Species & Stream/river & Lake and pond \\
\hline Navicula rhynchocephala Kütz. & $\mathrm{x}$ & $\mathrm{x}$ \\
\hline Navicula rostellata Kütz. & & $\mathrm{x}$ \\
\hline Navicula saxophila W. Bock ex Hust. & $\mathrm{x}$ & \\
\hline Navicula schroeteri Meister & $\mathrm{x}$ & \\
\hline Navicula scutiformis Grun. ex A. Schmidt & & $\mathrm{x}$ \\
\hline Navicula semen Ehr. & $\mathrm{x}$ & \\
\hline Navicula similis Krasske & & $\mathrm{x}$ \\
\hline Navicula striolata (Grun.) Lange-Bertalot & $\mathrm{x}$ & \\
\hline Navicula stroemii Hust. & $\mathrm{x}$ & $\mathrm{x}$ \\
\hline Navicula subminuscula Manguin & & $\mathrm{x}$ \\
\hline Navicula submuralis Hust. & $\mathrm{x}$ & \\
\hline Navicula subrhynchocephala Hust. & $\mathrm{x}$ & \\
\hline Navicula tenelloides Hust. & $\mathrm{x}$ & \\
\hline Navicula tridentula Krasske & & $\mathrm{x}$ \\
\hline Navicula tripunctata (Müller) Bory & $\mathrm{x}$ & \\
\hline Navicula variostriata Krasske & $\mathrm{x}$ & \\
\hline Navicula veneta Kütz. & $\mathrm{x}$ & $\mathrm{x}$ \\
\hline Navicula viridula (Kütz.) Kütz. & $\mathrm{x}$ & \\
\hline Navicula vulpina Kütz. & $\mathrm{x}$ & $\mathrm{x}$ \\
\hline Neidium affine (Ehr.) Pfitzer & $\mathrm{x}$ & \\
\hline Neidium affine v. longiceps (Greg.) Cl. & $\mathrm{x}$ & $\mathrm{x}$ \\
\hline Neidium alpinum Hust. & & $\mathrm{x}$ \\
\hline Neidium ampliatum (Ehr.) Krammer & & $\mathrm{x}$ \\
\hline Neidium bisulcatum (Lagerstedt) Cl. & $\mathrm{x}$ & $\mathrm{x}$ \\
\hline Neidium dubium (Ehr.) Cl. & $\mathrm{x}$ & \\
\hline Neidium iridis (Ehr.) Cl. & $\mathrm{x}$ & $\mathrm{x}$ \\
\hline Neidium productum (Sm.) Cl. & $\mathrm{x}$ & \\
\hline Nitzschia acicularis (Kütz.) W. Sm. & $\mathrm{x}$ & $\mathrm{x}$ \\
\hline Nitzschia acuminata (W. Sm.) Grun. & $\mathrm{x}$ & \\
\hline Nitzschia alpina Hust. & $\mathrm{x}$ & $\mathrm{x}$ \\
\hline Nitzschia amphibia Grun. & $\mathrm{x}$ & $\mathrm{x}$ \\
\hline Nitzschia angustata (W. Sm.) Grun. & $\mathrm{x}$ & $\mathrm{x}$ \\
\hline Nitzschia clausii Hantz. & $\mathrm{x}$ & \\
\hline Nitzschia communis Rabh. & $\mathrm{x}$ & $\mathrm{x}$ \\
\hline Nitzschia commutata Grun. & $\mathrm{x}$ & \\
\hline Nitzschia desortorum Hust. & & $\mathrm{x}$ \\
\hline Nitzschia dissipata (Kütz.) Grun. & $\mathrm{x}$ & $\mathrm{x}$ \\
\hline Nitzschia dissipata v. media (Hantz.) Grun. & $\mathrm{x}$ & \\
\hline Nitzschia dubia W. Sm. & $\mathrm{x}$ & \\
\hline Nitzschia filiformis (W. Sm.) Hust. & $\mathrm{x}$ & $\mathrm{x}$ \\
\hline Nitzschia flexa Schumann & $\mathrm{x}$ & \\
\hline Nitzschia flexioides Geitler & $\mathrm{x}$ & \\
\hline Nitzschia fonticola (Grtun.) Grun. & $\mathrm{x}$ & \\
\hline Nitzschia frustulum (Kütz.) Grun. & $\mathrm{x}$ & $\mathrm{x}$ \\
\hline Nitzschia hantzschiana Rabh. & $\mathrm{x}$ & \\
\hline Nitzschia heufleriana Grun. & $\mathrm{x}$ & \\
\hline Nitzschia hybrida Grun. & $\mathrm{x}$ & \\
\hline Nitzschia inconspicua Grun. & $\mathrm{x}$ & \\
\hline Nitzschia intermedia Hantz. ex Cl. \& Grun. & & $\mathrm{x}$ \\
\hline Nitzschia linearis West & $\mathrm{x}$ & $\mathrm{x}$ \\
\hline Nitzschia linearis v. tenuis (W. Sm.) Grun. & $\mathrm{x}$ & \\
\hline Nitzschia microcephala Grun. & $\mathrm{x}$ & \\
\hline Nitzschia palea (Kütz.) W. Sm. & $\mathrm{x}$ & $\mathrm{x}$ \\
\hline Nitzschia paleacea Grun. & $\mathrm{x}$ & $\mathrm{x}$ \\
\hline Nitzschia pellucida Grun. & $\mathrm{x}$ & \\
\hline Nitzschia perminuta (Grun.) M. Peragallo & $\mathrm{x}$ & $\mathrm{x}$ \\
\hline Nitzschia plana W. Sm. & $\mathrm{x}$ & \\
\hline Nitzschia pusilla Grun. & $\mathrm{x}$ & \\
\hline Nitzschia sigma (Kütz.) W. Sm. & $\mathrm{x}$ & \\
\hline Nitzschia sigmoidea (Nitzsch) W. Sm. & $\mathrm{x}$ & \\
\hline Nitzschia sublinearis Hust. & $\mathrm{x}$ & \\
\hline Nitzschia umbonata (Ehr.) Lange-Bertalot & $\mathrm{x}$ & \\
\hline Nitzschia vermicularis (Kütz.) Hantz. & $\mathrm{x}$ & $\mathrm{x}$ \\
\hline
\end{tabular}


APPENDIX 2. Continued.

\begin{tabular}{|c|c|c|}
\hline Species & Stream/river & Lake and pond \\
\hline Orthoseira dendroteres (Ehr.) Round, Crawford, Mann & $\mathrm{x}$ & \\
\hline Orthoseira roeseana (Rabh.) O’Meara & $\mathrm{x}$ & $\mathrm{x}$ \\
\hline Pinnularia appendiculata (C. Ag.) Cl. & & $\mathrm{x}$ \\
\hline Pinnularia borealis Ehr. & $\mathrm{x}$ & $\mathrm{x}$ \\
\hline Pinnularia brevicostata $\mathrm{Cl}$. & $\mathrm{x}$ & \\
\hline Pinnularia dactylus Ehr. & $\mathrm{x}$ & \\
\hline Pinnularia divergens $\mathrm{W}$. Sm. & $\mathrm{x}$ & $\mathrm{x}$ \\
\hline Pinnularia gibba Ehr. & $\mathrm{x}$ & $\mathrm{x}$ \\
\hline Pinnularia gibba v. linearis Hust. & $\mathrm{x}$ & \\
\hline Pinnularia hemiptera (Kütz.) Cl. & & $\mathrm{x}$ \\
\hline Pinnularia intermedia (Lagerstedt) Cl. & & $\mathrm{x}$ \\
\hline Pinnularia interrupta W. Sm. & $\mathrm{x}$ & $\mathrm{x}$ \\
\hline Pinnularia karelica $\mathrm{Cl}$. & $\mathrm{x}$ & \\
\hline Pinnularia lata (Bréb) W. Sm. & $\mathrm{x}$ & $\mathrm{x}$ \\
\hline Pinnularia maior (Kütz.) Cl. & $\mathrm{x}$ & \\
\hline Pinnularia microstauron (Ehr.) Cl. & $\mathrm{x}$ & $\mathrm{x}$ \\
\hline Pinnularia nobilis (Ehr.) Ehr. & $\mathrm{x}$ & \\
\hline Pinnularia obscura Krasske & $\mathrm{x}$ & $\mathrm{x}$ \\
\hline Pinnularia stomatophora (Grun.) Cl. & $\mathrm{x}$ & \\
\hline Pinnularia streptoraphe $\mathrm{Cl}$. & $\mathrm{x}$ & $\mathrm{x}$ \\
\hline Pinnularia subcapitata W. Greg. & $\mathrm{x}$ & $\mathrm{x}$ \\
\hline Pinnularia subrostrata Lohman \& Andrews & $\mathrm{x}$ & \\
\hline Pinnularia sudetica (Hilse) Peragallo & $\mathrm{x}$ & \\
\hline Pinnularia viridis (Nitzsch.) Ehr. & $\mathrm{x}$ & $\mathrm{x}$ \\
\hline Placoneis clematis (Grun.) Cox & $\mathrm{x}$ & \\
\hline Placoneis elginensis (Greg.) Cox & $\mathrm{x}$ & \\
\hline Placoneis explanata (Hust.) Lange-Bertalot & $\mathrm{x}$ & \\
\hline Planothidium delicatulum (Kütz.) Round \& Bukht. & $\mathrm{x}$ & $\mathrm{x}$ \\
\hline Planothidium dubium (Grun.) Round \& Bukht. & $\mathrm{x}$ & \\
\hline Planothidium lanceolatum (Bréb. ex Kütz.) Round \& Bukht. & $\mathrm{x}$ & $\mathrm{x}$ \\
\hline Planothidium oestrupii (Cl.-Euler) Round \& Bukht. & $\mathrm{x}$ & \\
\hline Planothidium rostratum (Øestrup) Lange-Bertalot & $\mathrm{x}$ & \\
\hline Pleurosigma delicatulum W. Sm. & $\mathrm{x}$ & \\
\hline Pleurosira laevis (Ehr.) Comprère & $\mathrm{x}$ & \\
\hline Psammothidium bioretii (Germain) Bukht. \& Round & $\mathrm{x}$ & $\mathrm{x}$ \\
\hline Psammothidium didymum (Hust.) Bukht. \& Round & & $\mathrm{x}$ \\
\hline Psammothidium grischumum f. daonensis (Lange-Bertalot) Bukht. \& Round & $\mathrm{x}$ & \\
\hline Psammothidium helveticum (Hust.) Bukht. \&Round & $\mathrm{x}$ & $\mathrm{x}$ \\
\hline Psammothidium levanderi (Hust.) Bukht. \& Round & $\mathrm{x}$ & $\mathrm{x}$ \\
\hline Psammothidium marginulata (Grun.) Bukht. \& Round & & $\mathrm{x}$ \\
\hline Psammothidium rossi (Hust.) Bukht. \& Round & & $\mathrm{x}$ \\
\hline Psammothidium subatomoides (Hust.) Bukht. \& Round & & $\mathrm{x}$ \\
\hline Pseudostaurosira brevistriata (Grun.) Williams \& Round & $\mathrm{x}$ & $\mathrm{x}$ \\
\hline Pseudostaurosira parasitica (W. Sm.) Morales & $\mathrm{x}$ & $\mathrm{x}$ \\
\hline Pseudostaurosira robusta (Fusey) Williams \& Round & & $\mathrm{x}$ \\
\hline Puncticulata bodanica (Eulenstein ex Grun.) Håkansson & $\mathrm{x}$ & \\
\hline Reimeria sinutata (Greg.) Kociolek \& Stoermer & $\mathrm{x}$ & $\mathrm{x}$ \\
\hline Rhoicosphenia abbreviata (C. Ag.) Lange-Bertalot B & $\mathrm{x}$ & \\
\hline Rhopalodia gibba (Ehr.) O. Müll. & $\mathrm{x}$ & $\mathrm{x}$ \\
\hline Rhopalodia gibba v. minuta Krammer & $\mathrm{x}$ & \\
\hline Rhopalodia gibberula (Ehr.) O. Müll. & $\mathrm{x}$ & $\mathrm{x}$ \\
\hline Rossithidium linearis (W. Sm.) Round \& Bukht. & $\mathrm{x}$ & \\
\hline Rossithidium nodosum (Cl.) M. Aboal & $\mathrm{x}$ & $\mathrm{x}$ \\
\hline Rossithidium petersenii (Hust.) Round \& Bukht. & $\mathrm{x}$ & $\mathrm{x}$ \\
\hline Rossithidium pusillum (Grun.) Round \& Bukht. & $\mathrm{x}$ & \\
\hline Sellaphora americana (Ehr.) Mann & $\mathrm{x}$ & \\
\hline Sellaphora laevissima (Kütz.) Mann & & $\mathrm{x}$ \\
\hline Sellaphora pupula (Kütz.) Mereschkowsky & $\mathrm{x}$ & $\mathrm{x}$ \\
\hline Sellaphora seminulum (Grun.) Mann & $\mathrm{x}$ & \\
\hline Stauroneis anceps Ehr. & $\mathrm{x}$ & $\mathrm{x}$ \\
\hline Stauroneis lundii Hust. & $\mathrm{x}$ & \\
\hline Stauroneis phoenicenteron (Nitz.) Ehr & $\mathrm{x}$ & $\mathrm{x}$ \\
\hline Stauroneis producta Grun. & $\mathrm{x}$ & \\
\hline
\end{tabular}


APPENDIX 2. Continued.

\begin{tabular}{|c|c|c|}
\hline Species & Stream/river & Lake and pond \\
\hline Stauroneis undata Hilse & $\mathrm{x}$ & \\
\hline Staurosira construens Ehr. & $\mathrm{x}$ & $\mathrm{x}$ \\
\hline Staurosira construens v. binodus (Ehr) Hamilton & & $\mathrm{x}$ \\
\hline Staurosira construens f. venter (Ehr.) Hamilton & $\mathrm{x}$ & $\mathrm{x}$ \\
\hline Staurosirella lapponica (Grun.) Williams \& Round & $\mathrm{x}$ & \\
\hline Staurosirella leptostauron (Ehr.) Williams \& Round & $\mathrm{x}$ & $\mathrm{x}$ \\
\hline Staurosirella pinnata (Ehr.) Williams \& Round & $\mathrm{x}$ & $\mathrm{x}$ \\
\hline Stenopterobia curvula (W. Sm.) Krammer & & $\mathrm{x}$ \\
\hline Stenopterobia densestriata (Hust.) Krammer & & $\mathrm{x}$ \\
\hline Stephanodiscus niagarae Ehr. & $\mathrm{x}$ & $\mathrm{x}$ \\
\hline Stephanodiscus parvus Stoermer \& Håkansson & & $\mathrm{x}$ \\
\hline Surirella amphioxys W. Sm. & $\mathrm{x}$ & \\
\hline Surirella angustata Kütz. & $\mathrm{x}$ & \\
\hline Surirella biseriata Bréb. & & $\mathrm{x}$ \\
\hline Surirella brebissonii Krammer \& Lange-Bertalot & $\mathrm{x}$ & \\
\hline Surirella brebissonii v. kuetzingii Krammer \& Lange-Bertalot & $\mathrm{x}$ & \\
\hline Surirella brightwellii $\mathrm{W}$. Sm. & $\mathrm{x}$ & \\
\hline Surirella elegans Ehr. & $\mathrm{x}$ & \\
\hline Surirella linearis W. Sm. & $\mathrm{x}$ & $\mathrm{x}$ \\
\hline Surirella minuta Bréb. & $\mathrm{x}$ & \\
\hline Surirella ovalis Bréb. & $\mathrm{x}$ & \\
\hline Surirella robusta Ehr. & & $\mathrm{x}$ \\
\hline Surirella splendida (Ehr.) Kütz. & $\mathrm{x}$ & $\mathrm{x}$ \\
\hline Surirella subsalsa W. Sm. & $\mathrm{x}$ & \\
\hline Surirella tenera W. Greg. & $\mathrm{x}$ & \\
\hline Tabellaria binalis (Ehr.) Grun. & $\mathrm{x}$ & \\
\hline Tabellaria fenestra (Lyngbya) Kütz. & $\mathrm{x}$ & $\mathrm{x}$ \\
\hline Tabellaria flocculosa (Roth) Kütz. & $\mathrm{x}$ & $\mathrm{x}$ \\
\hline Tetracyclus glans (Ehr.) Mills & $\mathrm{x}$ & \\
\hline Tetracyclus rupestris (Braun) Grun. & $\mathrm{x}$ & \\
\hline Tryblionella apiculata Greg. & $\mathrm{x}$ & \\
\hline Tryblionella calida (Grun.) Mann & $\mathrm{x}$ & \\
\hline Tryblionella compressa (Bailey) M. Poulin & $\mathrm{x}$ & \\
\hline Tryblionella corctata (Grun.) Mann & $\mathrm{x}$ & \\
\hline Tryblionella hungarica (Grun.) Frenguelli & $\mathrm{x}$ & \\
\hline Tryblionella levidensis W. Sm & $\mathrm{x}$ & \\
\hline Tryblionella littoralis (Grun.) Mann & $\mathrm{x}$ & \\
\hline Ulnaria ulna (Nitz.) P. Compère & $\mathrm{x}$ & $\mathrm{x}$ \\
\hline Ulnaria ulna v. acus (Kütz) Lange-Bertalot & $\mathrm{x}$ & \\
\hline
\end{tabular}

